Bayraktar, ì. ve Durukan, E. (2020). Yüzey yapı değişiklikleri ile öğrencilerin okuduğunu anlama becerileri arasındaki ilişki üzerine bir inceleme. Ana Dili Eğitimi Dergisi, 8(2), 292-314.

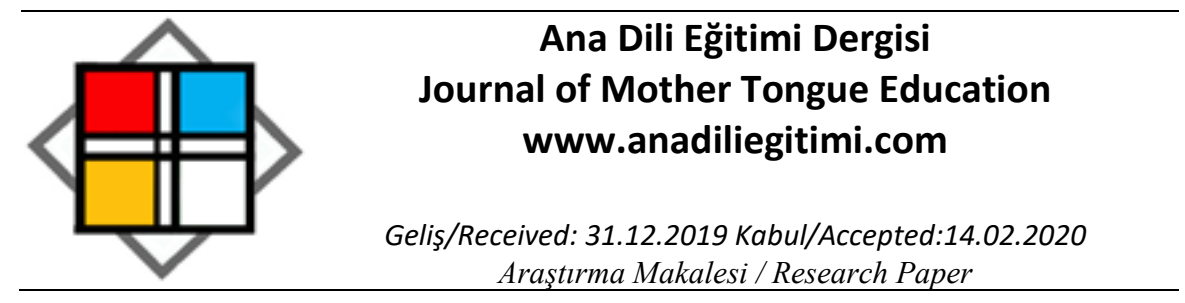

\title{
Yüzey Yapı Değişiklikleri ile Öğrencilerin Okuduğunu Anlama Becerileri Arasındaki İlişki Üzerine Bir İnceleme*
}

\author{
irem BAYRAKTAR ** \\ Erhan DURUKAN ${ }^{* * *}$
}

\begin{abstract}
Öz
Bu çalışmanın amacı, yüzey yapı değişikliğine uğramış bilgilendirici ve hikâye edici metinler ile okuduğunu anlama becerisi açısından düşük, orta ve yüksek seviye olarak gruplandırılan 7. sınıf öğrencilerinin okuduğunu anlama becerileri arasındaki ilişkiyi belirlemektir. Bu amaç doğrultusunda, Türkçe ders kitaplarında bulunan biri bilgilendirici biri hikâye edici türde olmak üzere iki metin üzerinde yapılan yüzey yapı değişiklikleri ile öğrenci seviye gruplarında okuduğunu anlama becerileri arasındaki ilişki tespit edilmiştir. Araştırma, nicel ve nitel verilerin bir arada toplandığı karma yöntem niteliği taşımaktadır. Araştırmanın çalışma grubunu Samsun ili Atakum ve İlkadım ilçesinde bulunan Millî Eğitim Bakanlığına bağlı devlet okullarında 7. sınıfta öğrenim gören 525 öğrenci oluşturmaktadır. Araştırmanın nicel verileri SPSS 21 programında frekans, yüzde, ANOVA, Friedman Testi analizleriyle; nitel verileri ise içerik analizi ile değerlendirilmiştir. Araştırma sonunda, yüzey yapı değişiklikleri ile öğrencilerin okuduğunu anlama becerileri arasında anlamlı bir ilişki olduğu; öğrencilerin metinler üzerinde yapılan yüzey yapı değişikliklerine karşı olumlu görüş belirttikleri sonuçlarına ulaşılmıştır.
\end{abstract}

Anahtar Kelimeler: Metin Dil Bilim, Yüzey Yapı, Okuduğunu Anlama, Anlam Kurma.

\section{An Investigation on the Effects of Surface Structure Changes on Students' Reading Comprehension}

\begin{abstract}
The aim of the study is to determine the relationship between the informative and narrative texts exposed surface structure and the reading comprehension skills of 7 th grade students assigned as low, medium and high levels. For this purpose, two texts from Turkish textbooks including an informative and a narrative text were selected and the changes in surface structure as well as their effects on the reading comprehension in the different student level groups were determined. The research is based on a mixed method and makes use of both quantitative and qualitative data. The study group consists of 525 students attending the 7th grade in state schools affiliated to the Ministry of National Education located in the districts Atakum and Illkadım in Samsun. The quantitative data was analysed with the SPSS 21 program using frequency, percentage, ANOVA and the Friedman Test; qualitative data was evaluated by content analysis. The study found that there is a significant correlation between the changes in the surface structure and students' reading comprehension. Students responded positively to the surface structure changes in texts.
\end{abstract}

Keywords: Text Linguistics, Surface Structure, Reading Comprehension, Construction of Meaning.

\footnotetext{
* Bu makale, "Yüzey Yapı Değişiklikleri ile Öğrencilerin Okuduğunu Anlama Becerileri Arasındaki ilişki Üzerine Bir Inceleme" adlı doktora tezinden üretilmiştir.

**Dr. Öğr. Üyesi, Ondokuz Mayıs Üniversitesi, Eğitim Fakültesi, Türkçe Eğitimi Ana Bilim Dalı, Samsun, urhanirem@gmail.com, ORCID: 0000-0002-3789-6731

**** Doç. Dr., Trabzon Üniversitesi, Eğitim Fakültesi, Türkçe Eğitimi Ana Bilim Dalı, Trabzon, erhandurukan@gmail.com, ORCID: 0000-0001-9600-3190
} 


\section{Giriş}

Insanın hayatına anlam verme ve kendisini ifade etme yollarının en önemli iki aracı anlama ve anlatma becerileridir. Bu becerilerin iyi olması ise ana diline hâkim olmak ile ilgilidir. İnsan hayatını çepeçevre saran ana dili, anlama ve anlatma imkânlarının geliştirilebilir olmasından dolayı öğrenme ve öğretme sürecinde büyük önem taşımaktadır.

$\mathrm{Bu}$ nedenle okullarda yapılan dil eğitiminin temel amacı insanların düşünce ve iletişim becerilerini geliştirmektir. Bir yönüyle anlatma bir yönüyle de anlama becerilerinin temel amaç olduğu dil becerisinin öğretiminde anlatma ile ilgili etkinlikler konuşma ve yazma gücünü; anlama ile ilgili etkinlikler ise okuma ve dinleme gücünü geliştirmeye yöneliktir (Kavcar, 1996; Özdemir, 2018).

Ana dili öğretiminin amaçları incelendiğinde insan hayatına birçok yönden fayda sağladığı görülmektedir. Bu nedenle ana dili derslerinin önemi bir kat daha artmaktadır. Ancak Türkiye'de ilkokul yıllarından yükseköğretim yıllarının sonlarına kadar ana dili olarak Türkçe eğitimi yapılıyor olsa da ana dili kullanımlarında sorunlar yaşandığı anlaşılmaktadır. Aynı zamanda öğrencilerin Türkçeyi yazılı ve sözlü olarak onlardan istenilen ölçüde etkili bir şekilde kullanamadığı görülmektedir (Alyılmaz, 2010).

$\mathrm{Bu}$ sorunların ortaya çıkmasının en önemli sebeplerinden biri de anlama becerisinin geliştirilmesinde büyük payı olan okuma becerisine gerekli özenin gösterilmemesidir. Okullarda yapılan eğitim-öğretim sürecinde öğrenmenin gerçekleşmesi için büyük ölçüde dil ile ilgili kaynakların kullanıldığı görülmektedir. Bu kaynakların en önemlilerden biri okuma becerisidir. Yalnızca Türkçe derslerinde değil, diğer derslerde de etkili bir okuma becerisinin gerektiği düşünülür. Bu nedenle, okuma konusunda sıkıntı yaşayan bir öğrencinin derslerinde başarılı olması beklenmemelidir (Demirel, 1996). Okuma becerisinin geliştirilmesi ile yalnızca öğrencinin derslerinde başarılı olması sağlanmaz. Okuma, aynı zamanda bireyin ruhsal ve düşünsel dünyasını da geliştiren bir etkinliktir. Bu nedenle insanın tüm hayatı boyunca okuma etkinliği yoluyla gerek akademik hayatına gerekse bireysel ve sosyal hayatına katkı sağlaması beklenir. Anlama becerisinin geliştirilmesinde okuma konusuna verilen önem de buradan kaynaklanmaktadır.

Bu nedenle ders kitaplarına seçilecek olan metinlerin -okuru aynı zamanda çocuk olanöğrencilerin ilgisini çekebilecek, yazın dünyasını tanıyabilecek, kişilik ve ruh gelişimlerine katkı sağlayabilecek mahiyette olması önem taşımaktadır. Aynı zamanda bu metinlerin öğrencilerin seviyelerine uygun olması da beklenir. Öğrenciler seviyelerinin ne çok altında ne de çok üstünde metinlerle karşılaşmalıdır.

Şüphesiz, öğrencilerin söz varlığını geliştirmek, yeni kavramları tanıtmak amacıyla metinlerde anlamı bilinmeyen sözcüklere yer verilmesi gerekir. Ancak, okunabilirliği zor olan ya da çok fazla anlamı bilinmeyen sözcüğe yer verilmesi, okumaya karşı olumsuz bir tavrın ortaya çıkmasına neden olacağından metin seviyelerinin öğrenci seviyelerine göre düzenlenmesini gerekli kılmaktadır. Ana dili öğretimi aynı zamanda öğrencilerde rasyonel düşünce ile sezgisel düşünceyi oluşturmayı amaç edinmektedir. Çünkü ana dili öğretimi sözcüklerin yüzey yapı anlamlarının gizlediği derin anlamın öğrencilere kavratılmasına çok fazla yardımcı olur (Marshall, 1974).

Bir metnin derin yapı ve yüzey yapı unsurları ile çağrışımlar o metnin anlamını oluşturur. Sözcük, sözcük öbekleri ve cümle öbeklerinin ötesinde çağrışımlarla kurulmuş olan yorum zinciri mevcuttur. Bu sistemin dengeli bir dağılımı ile metnin çözümlemesi tam ve doğru olarak yapılabilir. Bir metnin kuruluşunda derin yapı ve yüzey yapı bağlantılarını tamamlayan anlam bağlantıları, metnin bir bütün olarak algılanmasını sağlamaktadır. Metnin doğru anlaşılması ve sağlam metinler kurulması, bu ilişkilerin iyi bilinmesiyle daha kolay bir biçimde gerçekleştirilebilir (Karpuz ve Akçataş, 2001). Bu nedenle okullarda yapılacak olan okuma alıştırmalarının ve etkinliklerinin öğrencilerin metni oluşturan anlam bağıntılarını kavramalarını geliştirecek şekilde planlanması gerekmektedir.

Metinlerden anlam kurma, okuma esnasında metnin yüzey yapısından derin yapısına doğru meydana gelmektedir. Metin okunurken görsel işlemlerin başlamasıyla birlikte harfler sese dönüştürülmektedir. Bu seslerin meydana getirdiği işitme imgeleri aracılığıyla derin yapıda bulunan anlam zincirine ulaşılmaktadır. Okuma eğitiminde, anlamın yüzey yapıdan derin yapıya taşınma sürecinin bilinmesinde ve bu süreci etkileyen unsurların öğrenilmesinde fayda görülmektedir. "Kelime tanıma, kelime ayırt etme, edinilmiş bilgi, ön bilgi, bürün olguları, akıcılık, önvarsayım, sezdirim, alıcı 
kelime hazinesi, tutarlıık, bağdaşıklık ve noktalama işaretleri" gibi kavramların okuma becerisinin geliştirilmesine etki ettikleri görülmektedir (Onan, 2015). Bu nedenle, okuma becerisinin geliştirilmesi için okullarda yapılacak eğitimde bu kavramların içerdiği noktalara dikkat edilmesinde fayda görülmektedir.

Türkçe Dersi Öğretim Programı'nda ders kitaplarına seçilecek metinler için birtakım ölçütler getirilmiştir. 2019 Türkçe Dersi Öğretim Programı'nda geçen "Seçilen metinler ikincil aktarımlar yerine yazarın eserinden alınmalıdır" ifadesi ile metinler üzerinde herhangi bir düzeltme yapılamayacağı vurgulanmıştır. Bu ilke geçmiş yıllarda uygulanmadığı için ders kitaplarında düzenlenmiş, sadeleştirilmiş, kısaltılmış metinler yer almıştır. Ancak metinler üzerinde yapılacak düzenleme çalışmalarında standart ölçütler sağlanmamıştır. Bu durum, öğrenci seviyeleri arasında bulunan farklııklar nedeniyle metin düzenleme çalışmalarına ihtiyaç olduğu hâlde nitelikli düzenlemelerin yapılamamasına sebebiyet vermektedir.

2019 Türkçe Dersi Öğretim Programı́nda metin düzenlemesine çok kısıtlı bir şekilde imkân tanınmıştır. Ancak bu durum metinlerin öğrenci seviyelerine göre düzenlenmesinin önünde bir engel oluşturmaktadır. Ders kitaplarına seçilecek metinlerin bir ölçüde öğrenci seviyesine göre düzenlenmesi gerekmektedir. Bunun nedeni okuma sırasında kimi öğrenci daha az şeye ihtiyaç duyarken kimi öğrenci daha fazla şeye ihtiyaç duyabilir (Johnson, 2017). Dolayısıyla öğrencilere seviyelerine göre düzenlenmemiş metinleri okutmaya çalışmak, bu ihtiyaçların karşılanmasına bir engel oluşturarak başarısızlığa neden olabilir.

Okuma ve anlama öğretimine ilişkin yapılan araştırmalar, son yıllarda yazılı bir metni anlama becerisinin gelişimini etkileyen faktörler üzerinde durmaktadır. Bu araştırmalarda, okuduğunu doğru bir şekilde anlama becerisinin göstergesi olarak, okurun metinle ilgili sorulara cevap verme, metinde verilen görüşleri kendi ifadeleriyle dile getirme gibi işlemlere işaret edildiği görülmektedir (Demirel, 1996).

Türkçe derslerinin de odak noktasını oluşturan metinler, metinlerden anlam kurma, metin türleri ve metinlerin niteliği gibi konular, ders kitaplarının önemli bir materyal olarak kullanılması ile daha önemli bir hâle gelmiştir. Metin merkezli öğretimin yapılmasının bir sonucu olarak öğretmenler, öğrencilerinin okuma, anlama ve yorumlama becerilerini de değerlendirmek zorunda kalmışlardır. Bu durumda da, doğru ve etkili bir şekilde okuma, anlam kurma, çıkarım ve yorum yapabilme yeteneği günümüz dil ve zihin çalışmalarının konusu hâline gelmiştir (Bayraktar ve Durukan, 2016). Bu nedenle son yıllarda önemi gittikçe artan okuma becerisi ile metinlerin alımlanması arasındaki ilişkinin incelendiği görülmektedir.

Gerek Türkçe derslerinde gerekse diğer derslerde en fazla kullanılan ders materyali olması sebebiyle ders kitaplarında yer alan metinler üzerinde birçok çalışma yapıldığı görülmektedir. Ancak metinler üzerinde yapılan değişiklikler ile öğrencilerin okuduğunu anlama becerileri arasında nasıl bir ilişki olduğu üzerinde uygulamalı bir çalışma yapılmaması önemli bir eksikliktir.

Bu nedenle ilgili literatürde metinler üzerinde yapılan değişiklikler ile öğrencilerin okuduğunu anlama becerileri arasında nasıl bir ilişki olduğunu ortaya koyan çalışmaların eksikliği, araştırmanın gerekçesini oluşturmaktadır. Ders kitaplarına seçilen metinlerin öğrencilerin anlam kurmalarına yardımcı olacak mahiyette düzenlenmesi gerektiği fikrinden hareketle bu çalışmanın ilgili literatüre katkı sağlayacağı düşünülmektedir.

Bu çalışmanın amacı, yüzey yapı değişikliğine uğramış bilgilendirici ve hikâye edici metinler ile düşük, orta ve yüksek seviye olarak gruplandıılan 7. sınıf öğrencilerinin okuduğunu anlama becerileri arasındaki ilişkinin belirlenmesidir. Bu doğrultuda "Yüzey yapısı değiştirilmiş metinler ile öğrencilerin okuduğunu anlama becerileri arasındaki ilişki ne düzeydedir?" probleminden yola çıkarak aşağıda sıralanan alt problemlere cevap aranması amaçlanmıştır:

1. Özgün metinleri okuyan öğrenciler ile yüzey yapısı değiştirilmiş metinleri okuyan öğrenci gruplarının okuduğunu anlama başarı puanları arasında anlamlı farklılık var mıdır?

1.1. Yüzey yapısı değiştirilmiş metinler ile "düşük" seviyeli öğrenci gruplarının okuduğunu anlaması arasında anlamlı bir ilişki var mıdır?

1.2. Yüzey yapısı değiştirilmiş metinler ile "orta" seviyeli öğrenci gruplarının okuduğunu anlaması arasında anlamlı bir ilişki var mıdır? 
1.3. Yüzey yapısı değiştirilmiş metinler ile "yüksek" seviyeli öğrenci gruplarının okuduğunu anlaması arasında anlamlı bir ilişki var mıdır?

2. Metinler üzerinde yapılan yüzey yapı değişimleri ile ilgili olarak öğrenci görüşleri nelerdir?

\section{Araştırmanın Modeli}

\section{Yöntem}

Araştırmada, karma yöntem deseni kullanılmıştır. Karma yöntemli desen, bir çalışmada nitel ve nicel araştırmaların ve bu araştırmalardan elde edilen verilerin birleştirilmesini ya da bütünleştirilmesini gerektiren bir yöntemdir. Karma yöntemler alanında sosyal bilimlerde başlıca yakınsayan desen, açımlayıcı sıralı desen ve keşfedici sıralı desen modellerinin kullanıldığı görülmektedir (Creswell, 2016).

$\mathrm{Bu}$ araştırmada veriler, nicel ve nitel veri toplama teknikleri ile toplanmıştır. Araştırmada öğrencilerin okuduğunu anlama genel başarı düzeylerini, metinlerin okunabilirlik seviyelerini, öğrencilerin metinlerden okuduğunu anlama başarı düzeylerini ve okumaya olan tutumlarını tespit etmek için nicel veriler; metinler üzerinde yapılan değişimler için öğrenci görüşlerini tespit etmek için nitel veriler kullanılmıştır.

Araştırmada nicel ve nitel verilerin birlikte toplanmasının nedeni, her iki veri tabanından elde edilen bulguların karşılaştııılarak birbirlerini doğrulayıp doğrulamadı̆̆ını belirlemek ve araştırma probleminin tam olarak anlaşılmasını sağlamaktır. Araştırmanın nicel verileri Okuduğunu Anlama Başarı Testi, Ateşman Okunabilirlik Formülü, Akşamla Gelen Metni Okuduğunu Anlama Soruları, Tac Mahal Metni Okuduğunu Anlama Soruları ve Okuma Tutum Ölçeği ile; araştırmanın nitel verileri ise Metinler Üzerinde Yapılan Değişimler İ̧̧in Öğrenci Görüşme Formu ile toplanmıştır. Araştırmanın nicel ve nitel verileri, araştırma sürecinde birlikte toplanmıştır.

\section{Araştırma Grubu}

Araştırma grubunu Samsun ili Atakum ve İlkadım ilçesinde bulunan Millî Eğitim Bakanlığına bağlı devlet okullarında 7. sınıfta öğrenim gören 525 öğrenci oluşturmaktadır. Araştırma grubu, kolay ulaşılabilir örnekleme yöntemiyle seçilmiştir.

Araştırma grubunda bulunan öğrenciler arasında seviye gruplarını oluşturmak amacıyla 40 soruluk Okuduğunu Anlama Başarı Testi'nin pilot uygulaması 4 farklı okulda 132 7. sınıf öğrencisine uygulanmıştır. Bu pilot uygulama sonunda soruların madde güçlük analizi hesaplanmıştır. Aynı zamanda bu test için uygulamanın yapıldığı okullarda görev yapan Türkçe öğretmenleri ve akademisyenlerden uzman görüşü alınarak Okuduğunu Anlama Başarı Testi'ne 19 soruluk son hâli verilmiştir.

Daha sonra 5 farklı okulda öğrenim gören 525 öğrenci Okuma Tutum Ölçeği ve Okuduğunu Anlama Başarı Testi'ni yanıtlamışlardır. Okuma Tutum Ölçeği ve Okuduğunu Anlama Başarı Testi'nden elde edilen sonuçlara göre öğrenciler başarı seviyelerine göre düşük, orta ve yüksek olarak gruplara ayrılmıştır. Bu gruplar da kendi içinde başarı puanlarına göre "Düşük 1, Düşük 2, Düşük 3; Orta 1, Orta 2, Orta 3; Yüksek 1, Yüksek 2, Yüksek 3" olmak üzere birbirine denk gruplara ayrılmışlardır.

\section{Veri Toplama Araçları \\ Yüzey Yapısı Değiştirilen Metinler}

Yüzey yapısı değiştirilmiş metinler ile öğrencilerin okuduğunu anlama becerileri arasındaki ilişkiyi incelemek amacıyla Türkçe ders kitaplarından biri bilgilendirici biri hikâye edici olmak üzere iki metin seçilmiştir. Bu araştırma, Samsun iline bağlı ortaokullarda okuyan 7. sınıf öğrencileri ile yürütüldüğünden bu ilde okutulan Türkçe ders kitapları, öğrencilerin metinlerle daha önce karşılaşma intimali göz önünde bulundurularak metin seçiminde kapsam dışı bırakılmıştır. Bu nedenle Samsun ilinde okutulmayan Türkçe ders kitaplarında bulunan bilgilendirici ve hikâye edici metinler bir havuzda toplanmıştır. Bu metinler için uzman görüşü alınarak araştırmada kullanılan metinler seçilmiştir. 
Bilgilendirici türde Tac Mahal; hikâye edici türde ise Akşamla Gelen metni seçilmiştir. Tac Mahal, 8. Sınıf Türkçe Ders Kitabı'nda (Evren Yayıncılık, 2015-2016); Akşamla Gelen metni ise 6. Sınıf Türkçe Ders Kitabı'nda (Ögüun Yayınları, 2015-2016) yer almaktadır.

Tac Mahal ve Akşamla Gelen metinleri üzerinde yüzey yapı değişimleri araştırmacı tarafından yapılmıştır. Bu değişimler Faigley ve Witte (1981)'nin ortaya koyduğu metin revizyonu taksonomisi dikkate alınarak yapılmıştır. Bu taksonomiye göre anlamı koruyan yüzey yapı değişimleri ekleme, çıkarma, değiştirme, yer değiştirme, bölme ve birleştirme işlemlerinden oluşmaktadır. Akşamla Gelen ve Tac Mahal metinleri araştırmacı tarafından bu işlemlere tabi tutularak metinlerin seviyelendirme çalışmaları yapılmıştır. Metinlerin özgün hâlleri "zor" seviye; değişim yapıldıktan sonra elde edilen hâlleri ise "orta" ve "kolay" seviye olarak belirlenmiştir. Böylelikle her iki metin türü için kolay, orta ve zor seviye olmak üzere üç metin elde edilmiştir.

Akşamla Gelen ve Tac Mahal metinlerinin okunabilirlik düzeylerini belirlemek amacıyla araştırmacı tarafından Okunabilirlik Formülü kullanılarak sonuçlar hesaplanmıştır. Metin Üzerinde Yapılan Değişimler İ̧̧in Öğrenci Görüşme Formu uygulamaların yapıldığı farklı okullarda araştırmacı tarafından; Okuduğunu Anlama Başarı Testi, Akşamla Gelen Metni Okuduğunu Anlama Soruları, Tac Mahal Metni Okuduğunu Anlama Soruları ve Okuma Tutum Ölçeği ise uygulamaların yapıldığı farklı okullarda görev yapan Türkçe öğretmenleri tarafından toplanmıştır.

\section{Okuma Tutum Ölçeği}

Araştırmada öğrencilerin okumaya karşı olan tutumlarını belirlemek amacıyla Sallabaş (2008) tarafından geliştirilen Okuma Tutum Ölçeği kullanılmıştır.

Ölçek 20 maddeden oluşmaktadır. Ölçekteki maddeler "Kesinlikle Katılmıyorum", "Katılmıyorum", "Kararsızım", "Katılıyorum" ve "Kesinlikle Katılıyorum" şeklinde puanlanmakta olup olumlu maddeler 1-2-3-4-5, olumsuz maddeler ise 5-4-3-2-1 olmak üzere beşli likert tipinde derecelendirilmiştir. Likert tipi ölçeklerin güvenirliğini ölçmek için kullanılan Cronbach Alfa katsayısı, Okuma Tutum Ölçeği'nin iç tutarlılığını belirlemek için hesaplanmıştır. Okuma Tutum Ölçeği'nin maddelerine ilişkin Cronbach Alfa katsayısı $\alpha=0.86$ olarak bulunmuştur (Sallabaş, 2008).

\section{Okuduğunu Anlama Başarı Testi}

Öğrencilerin okuduğunu anlama becerilerini ölçmek üzere Okuduğunu Anlama Başarı Testi kullanılmıştır. Bu test, Millî Eğitim Bakanlığı tarafından geçmiş yıllarda hazırlanan Orta Öğretim Kurumları Öğrenci Seçme ve Yerleştirme Sınavı (1998-2008), 7. Sınıf Değerlendirme Sınavı ve kazanım kavrama testlerinin sözcükte anlam, cümlede anlam, paragrafta anlam konularından seçilen 40 sorudan oluşmaktadır. Bu sorular pilot uygulama için düzenlenmiştir.

Okuduğunu Anlama Başarı Testi'nin 40 sorudan oluşan hâli pilot olarak 1327 . sınıf öğrencisine uygulanmıştır. Uygulama esnasında Türkçe öğretmenlerinin sorular ile ilgili görüşleri alınmıştır. Aynı zamanda akademisyenlerden de bu sorular ile ilgili görüşler alınmıştır. Alınan bu görüşler doğrultusunda sorulardan birinin hatalı olması nedeni ile bu soru testten çıkarılmıştır. Bu uygulama sonunda soruların madde güçlük endeksleri hesaplanmıştır.

Bir test maddesinin güçlüğü (p), testin uygulandığı grupta o maddeye doğru cevap veren öğrencilerin yüzdesidir. Madde güçlüğü, bir maddeye doğru cevaplayan öğrencilerin sayısının toplam öğrenci sayısına bölünmesiyle hesaplanır. Bir maddenin güçlük endeksi (p), 0.00 ile +1.00 arasında değişir. Hiçbir öğrencinin cevaplayamadığı bir maddenin güçlük derecesi 0.00 ; bütün öğrencilerin cevapladığı bir maddenin güçlük derecesi ise +1.00 'dır (Tekin, 1984).

Bu doğrultuda madde güçlük endeksi $0,30^{\prime}$ un altında ve $0,80^{\prime}$ in üzerinde olan sorular testten çıkarılmıştır. Testte yer alan soruların konu dağılımları eşit olarak dağıtılmıştır. Bu işlemlerin ardından Okuduğunu Anlama Başarı Testi'nde 19 soru kalmıştır. Bu soru sayısı 7. sınıf öğrencilerinin girdikleri merkezi sınavlarda sorulan soru sayısına yakın olduğu için yeterli görülmektedir. 


\section{Metinler Üzerinde Yapılan Değişimler İ̧̧in Öğrenci Görüşme Formu}

Araştırmada öğrencilerin metinler üzerinde yapılan değişimler hakkında görüşlerini tespit etmek amacıyla araştırmacı tarafından hazırlanan Metinler Üzerinde Yapılan Değiş̧imler İçin Öğrenci Görüşme Formu kullanılmıştır.

Görüşme formu, araştırmacının önceden belirlediği sorular hakkında ayrıntılı bilgi alma amacıyla hazırlanan ve araştırma problemi ile ilgili tüm boyutların ve soruların kapsanmasını güvence altına almak için geliştirilmiş bir yöntemdir (Yıldırım ve Şimşek, 2011).

Metinler Üzerinde Yapılan Değişimler İçin Öğrenci Görüşme Formu'nda öğrencilere, Tac Mahal ve Akşamla Gelen metinlerinin yüzey yapıları değişmeden önceki özgün hâlleri ile yüzey yapısı değiştirilmiş hâlleri sunularak hangisini tercih ettikleri ve nedeni sorulmuştur. Öğrenciler daha iyi anladıklarını düşündükleri seçenekleri işaretleyip bu seçenekleri tercih etme nedenlerini yazmışlardır.

Bu yönüyle araştırmada kullanılan görüşme formu "yarı yapılandırılmış görüşme formu"dur. Bu görüşme formu hem sabit seçenekli hem de ilgili alanda derinlemesine gidebilmeyi sağlayabilir. Bu nedenle, bu tür görüşme formları, analizlerin kolaylığı, görüşülenlere kendini ifade etme imkânı ve gerektiğinde derinlemesine bilgi sağlama gibi avantajlara sahiptir (Büyüköztürk, Kılıç Çakmak, Akgün, Karadeniz ve Demirel, 2012).

\section{Okunabilirlik Formülü}

Araştırmada kullanılan metinlerin okunabilirlik düzeylerinin belirlenmesi amacıyla Flesch tarafından geliştirilen ve Ateşman (1997) tarafından Türkçeye uyarlanan Okunabilirlik Formülü kullanılmıştır. Metinlerin okunabilirlik düzeyleri aşağıdaki formüle göre hesaplanmıştır:

Okunabilirlik Sayısı $=198,825-40,175 . x 1-2,610 . x 2$

$\mathrm{x} 1=$ Hece olarak ortalama kelime uzunluğu

x2 = Kelime olarak ortalama cümle uzunluğu

Metinlerin okunabilirlik düzeyleri hesaplanırken metinlerin 100 kelimelik kesitleri alınmıştır. Ortalama kelime uzunluğunu hesaplamak için heceler; ortalama cümle uzunluğunu hesaplamak için kelimeler sayılmıştır. Ancak 100 kelime sonunda son cümle tamamlanmamışsa toplam cümle sayısını elde etmek için yüz kelimede sayılan cümlenin kelime sayısı o cümlenin toplam kelime sayısına bölünmüştür. Metinlerin okunabilirliği hesaplandıktan sonra metinler, Ateşman'ın Türkçe metinler için ortaya koyduğu okunabilirlik sınıflandırmasına göre düzenlenmiştir.

\section{Akşamla Gelen ve Tac Mahal Metni Okuduğunu Anlama Soruları}

Akşamla Gelen ve Tac Mahal Metni Okuduğunu Anlama Soruları öğrencilerin okuduğunu anlama becerilerini farkı türden ölçen sorulardan meydana gelmiştir. Metni anlama soruları açık uçlu 3 soru, çoktan seçmeli 5 soru, doğru/yanlış 5 soru, eşleştirme 1 soru, boşluk doldurma 1 sorudan oluşmaktadır. Sorular Türkçe Dersi Öğretim Programı́nın okuma ve anlama kazanımları dikkate alınarak hazırlanmıştır. Sorular hazırlandıktan sonra 3 farklı okulda görev yapan Türkçe öğretmenleri ve akademisyenler tarafından uzman görüşü alınarak soruların son hâli verilmiştir.

Akşamla Gelen ve Tac Mahal Metni Okuduğunu Anlama Soruları'nın puanlama anahtarı; açık uçlu sorular 45 puan, çoktan seçmeli sorular 25 puan, doğru/yanlış sorusu 10 puan, eşleştirme sorusu 10 puan, boşluk doldurma sorusu 10 puan şeklindedir. Öğrencilerin verdikleri cevaplar bu puanlama anahtarına göre hesaplanmıştır. Açık uçlu sorular, metni özetleme, metne uygun başlık koyma ve metne ait iki adet soru oluşturma; çoktan seçmeli sorular, anlatım biçimi, metnin konusu, sözcükte anlam, metnin türü, nesnel/öznel yargı; doğru/yanlış soruları, düşünceyi geliştirme yolları, kişileştirme, söz sanatları, gerçek/gerçek dışı unsurlar, yansıma sözcükler; eşleştirme sorusu metnin zaman akışı içerisinde olayların gerçekleşme sırasını yazma ve boşluk doldurma sorusu metnin anahtar sözcüklerini bulma sorularından oluşmaktadır.

Akşamla Gelen Metni Okuduğunu Anlama Soruları ve Tac Mahal Metni Okuduğunu Anlama Soruları birbirine denk soru gruplarından oluşmaktadır. Bunun nedeni, iki veri toplama aracından elde edilen verilerin sorulan sorulara bağıı olarak değişme faktörünü ortadan kaldırmaktır. 


\section{Verilerin Toplanması}

Araştırmada ilk olarak öğrencilere bilgilendirici ve hikâye edici metinler verilerek bu metinlerde anlamını bilmedikleri kelimeleri tespit etmeleri istenmiştir. Bu uygulama 5 farklı okulda öğrenim gören toplam 100 7. sınıf öğrencisi ile yürütülmüştür. Öğrenciler metinlerde anlamını bilmedikleri kelimeleri işaretlemişlerdir. Daha sonra öğrencilerin tespit ettikleri bilinmeyen kelimeler araştırmacı tarafından frekans analizi ile hesaplanmıştır. Böylelikle metinlerin yüzey yapıları değiştirilirken öğrencilerin bilmedikleri kelimelerin göz önünde bulundurulması sağlanmıştır.

Tac Mahal metni en fazla bilinmeyen 10 kelime içerisinde beyit ve özel isimler olduğu için onların yerine anlamı bilinmeyen diğer sözcükler tespit edilmiştir.

Öğrencilerin metinde bilinmeyen sözcükleri tespit ettikleri uygulamadan sonra metinlerin kelime düzeyinde değişimleri yapılmıştır. Kelime düzeyinde yapılan değişimler için kelimelerin yalnızca eş anlamlı ya da Türkçe Sözlük'te yer alan birincil karşılıkları kullanılmamıştır. Kelimeler, cümle bağlamından hareketle o kelimenin ait olduğu anlamsal alandan seçilen kelimelerle değiştirilmiştir. Bu işlem yapıldıktan sonra 42 7. sınıf öğrencisinden tekrar anlamını bilmedikleri kelimeleri işaretlemeleri istenmiştir. Bu uygulamanın amacı araştırmacının metnin kelime düzeyinde değiştirdiği kelimeleri öğrencilerin bilip bilmeme durumlarını tespit etmektir. Yapılan bu çalışma sonucunda, araştırmacının bilinmeyen kelimeler yerine değiştirdiği kelimelerin öğrenciler tarafından anlamı bilinmeyen kelimeler için işaretlenmemiş olduğudur. Böylelikle öğrencilerin anlamını bilmedikleri kelimelerin anlamın bildikleri kelimelerle değiştirildiğinin güvenirliği sağlanmıştır.

Araştırmacı tarafından daha sonra Akşamla Gelen ve Tac Mahal metinlerinin diğer yüzey yapı değişimleri yapılmıştır. Bu değişimler Faigley ve Witte (1981)'nin ortaya koyduğu metin revizyonu taksonomisi dikkate alınarak yapıımıştır. Bu taksonomiye göre anlamı koruyan yüzey yapı değişimleri ekleme, çıkarma, değiştirme, yer değiştirme, bölme ve birleştirme işlemlerinden oluşmaktadır. Akşamla Gelen ve Tac Mahal metinleri araştırmacı tarafından bu işlemlere tabi tutularak metinlerin seviyelendirme çalışmaları yapılmıştır. Bu işlemlerin belirli oranlarda gerçekleşmesiyle kolay, orta ve zor metinlerin elde edilmesi sağlanmıştır.

$\mathrm{Bu}$ işlemler sonucunda elde edilen metinlerin okunabilirlik düzeyleri Ateşman (1997) tarafından Türkçeye uyarlanan Okunabilirlik Formülü ile hesaplanmıştır. Böylece metin seviyelendirmesinde metinlerin okunabilirlik düzeyleri de dikkate alınarak güvenilir sonuçlara ulaşmak hedeflenmiştir.

Araştırmacı tarafından yapılan yüzey yapı değişimlerinin her bir işlemi (ekleme, çıkarma, değiştirme, yer değiştirme, bölme, birleştirme), Metin Üzerinde Yapılan Değişimler Iç̧in Öğrenci Görüşme Formu ile 2 farklı okulda 40 ila 50 öğrenci tarafından değerlendirilmiştir. Öğrencilere metinlerde bulunan cümlelerin özgün ve değiştirilmiş hâlleri sunularak daha anlamlı olanı işaretlemeleri ve nedenini yazmaları istenmiştir. Böylelikle yüzey yapı değişim işlemlerinin öğrenciler tarafından nasıl anlamlandırıldığı tespit edilmiştir.

Öğrenci seviye gruplarını oluşturmak amacıyla 40 soruluk Okuduğunu Anlama Başarı Testi'nin pilot uygulaması 4 farklı okulda 132 7. sınıf öğrencisine uygulanmıştır. Bu pilot uygulama sonunda soruların madde güçlük analizi hesaplanmıştır. Aynı zamanda bu test için uygulamanın yapıldığı okullarda görev yapan Türkçe öğretmenleri ve akademisyenlerden uzman görüşü alınarak Okuduğunu Anlama Başarı Testi'ne 19 soruluk son hâli verilmiştir.

Daha sonra 5 farklı okulda öğrenim gören 525 öğrenci Okuma Tutum Ölçeği ve Okuduğunu Anlama Başarı Testi'ni yanıtlamışlardır. Okuma Tutum Ölçeği ve Okuduğunu Anlama Başarı Testi'nden elde edilen sonuçlara göre öğrenciler başarı seviyelerine göre düşük, orta ve yüksek olarak gruplara ayrılmıştır. Bu gruplar da kendi içinde başarı puanlarına göre "Düşük 1, Düşük 2, Düşük 3; Orta 1, Orta 2, Orta 3; Yüksek 1, Yüksek 2, Yüksek 3" olmak üzere birbirine denk gruplara ayrılmışlardır. Metin seviyeleri ve öğrenci grupları belirlendikten sonra yüzey yapısı değiştirilmiş bilgilendirici (Tac Mahal) ve hikâye edici (Akşamla Gelen) metinler öğrenci gruplarına dağıtılmıştır. Yüzey yapısı değiştirilmemiş metnin özgün hâli zor metin, yüzey yapısı belirli ölçülerde değiştirilmiş metinler ise orta ve kolay metin olarak belirlenmiştir. Zor metinleri "Düşük 1 , Orta 1 ve Yüksek 1" grubundaki öğrenciler; orta metinleri "Düşük 2, Orta 2, Yüksek 2" grubundaki öğrenciler; kolay metinleri “Düşük 3, Orta 3, Yüksek 3" grubundaki öğrenciler okumuşlardır. 
Öğrenciler daha sonra Akşamla Gelen metnini okuduktan sonra Akşamla Gelen Metni Okuduğunu Anlama Soruları'na; Tac Mahal metnini okuduktan sonra Tac Mahal Metni Okuduğunu Anlama Soruları'na cevap vermişlerdir. Veri toplama süreci sonunda elde edilen veriler daha sonra analize tabi tutulmuştur.

\section{Verilerin Analizi}

Araştırma verileri hem nicel hem nitel veri toplama teknikleri ile toplanmıştır. Araştırmanın nicel verileri Okuduğunu Anlama Başarı Testi, Ateşman Okunabilirlik Formülü, Akşamla Gelen Metni Okuduğunu Anlama Soruları, Tac Mahal Metni Okuduğunu Anlama Soruları ve Okuma Tutum Ölçeği ile; nitel verileri ise Metinler Üzerinde Yapılan Değişimler İçin Öğrenci Görüşme Formu ile toplanmıştır.

Metinlerin okunabilirlik düzeyleri Ateşman Okunabilirlik Formülü'ne göre hesaplanmıştır. Okunabilirlik Formülü'nden elde edilen hesaplamalar ve sınıflandırmaya göre metinlerin ders kitabında yer alan hâllerinin okunabilirlik düzeyleri aşağıdaki tabloda gösterilmiştir:

Tablo 1.

Ateşman Okunabilirlik Formülü'ne Göre Metinlerin Okunabilirlik Düzeyleri

\begin{tabular}{lcc}
\hline Metinler & Okunabilirlik Sayısı & Okunabilirlik Düzeyi \\
Akşamla Gelen & 41,98 & Zor \\
Tac Mahal & 48,25 & Zor \\
\hline
\end{tabular}

Yüzey yapısı değiştirilen metinlerin okunabilirlik düzeyleri Okunabilirlik Formülü ile tekrar hesaplanmıştır. Böylece metin seviyelendirmesinde metinlerin okunabilirlik düzeyleri de dikkate alınarak güvenilir sonuçlara ulaşmak hedeflenmiştir. Buna göre metinlerin seviyelendirildikten sonra okunabilirlik düzeyleri aşağıdaki tabloda gösterilmiştir:

Tablo 2.

Seviyelendirilmiş Metinlerin Okunabilirlik Düzeyleri

\begin{tabular}{lcc}
\hline Metinler & Okunabilirlik Sayısı & Okunabilirlik Düzeyi \\
Akşamla Gelen Kolay & 57,83 & Orta \\
Akşamla Gelen Orta & 53,12 & Orta \\
Tac Mahal Kolay & 64,19 & Orta \\
Tac Mahal Orta & 58,06 & Orta \\
\hline
\end{tabular}

Metinlerin yüzey yapı değişiklikleri yapıldıktan sonra Okunabilirlik Formülü'nden elde edilen hesaplamalara göre "zor" okunabilirlik düzeyinden "orta" okunabilirlik düzeyine ulaşıldığı görülmektedir.

Öğrenci seviye gruplarını elde etmek için 525 öğrencinin Okuma Tutum Ölçeği ile Okuduğunu Anlama Başarı Testi'nden aldıkları puanların ortalaması hesaplanmıştır. Bu hesaplamalar sonucunda en yüksek ortalamaya sahip öğrenciden başlamak üzere en düşük ortalamaya sahip öğrenciler sıralanmıştır. Buna göre Okuma Tutum Ölçeği ile Okuduğunu Anlama Başarı Testi'nden alınan en yüksek ortalamaya sahip öğrencinin ortalama puanı 51; en düşük ortalamaya sahip öğrencinin ortalaması ise $26,5^{\prime}$ tir. Bu sonuca göre yüksek seviyeli gruplar 51 ile 45,5; orta seviyeli gruplar 41,5 ile 40; düşük seviyeli gruplar 37 ile 26,5 ortalamaya sahip 60'şar öğrenciden oluşmaktadır. Her gruba seçilen 60 öğrencinin ortalama puanları dikkate alınarak 20'şer kişilik birbirine denk gruplar oluşturulmuştur. Düşük seviyeli gruplar kendi içinde D1-D2-D3; orta seviyeli gruplar O1-O2-O3; yüksek seviyeli gruplar Y1-Y2-Y3 olarak gruplandırılmıştır. Grupların cinsiyet ve ortalama puan dağılımı aşağıdaki tabloda gösterilmiştir: 
Tablo 3.

Tac Mahal ve Akşamla Gelen Metinlerini Okuyan Düşük-Orta-Yüksek Seviye Öğrenci Gruplarının Cinsiyet ve Ortalama Puan Dağılımı

\begin{tabular}{cccc}
\hline Gruplar & $\bar{X}$ & $K$ & Cinsiyet \\
\hline D1 & 33,95 & 10 & 10 \\
D2 & 34,00 & 11 & 9 \\
D3 & 34,12 & 9 & 11 \\
O1 & 40,55 & 11 & 9 \\
O2 & 40,55 & 12 & 8 \\
O3 & 40,55 & 10 & 10 \\
Y1 & 47,10 & 12 & 8 \\
Y2 & 47,07 & 11 & 9 \\
Y3 & 47,02 & 11 & 9 \\
\hline
\end{tabular}

Metinler Üzerinde Yapılan Değişimler için Öğrenci Görüşme Formu'nda öğrencilerin metinlerin değişimlerine yönelik sorulan sorulara verdikleri cevaplar üzerinde içerik analizi yöntemi uygulanmıştır. İçerik analizi yoluyla veriler, tanımlanmaya ve verilerin içinde saklı olabilecek gerçekler ortaya çıkarılmaya çalışılmaktadır. İçerik analizi, birbirine benzeyen verileri belirli kavram ve temalar çerçevesinde bir araya getirmek ve bunları okuyucunun anlayabileceği bir şekilde düzenleyerek yorumlamaktır (Yıldırım ve Şimşek, 2011).

Metinler Üzerinde Yapılan Değişimler İçin Öğrenci Görüşme Formu'nda ilk olarak veriler kodlanarak kategoriler belirlenmiştir. Kodların ve kategorilerin belirlenmesinden sonra elde edilen bulgular düzenlenerek değerlendirilmiştir.

Gruplar arasında başarı açısından farkı ortaya koyan istatistiksel yöntemlere karar vermek için SPSS 21 programında verilerin dağılımının normalliği incelenmiştir. Her bir gruptaki kişi sayısı 50'den küçük olduğu için normallik varsayımının testinde Shapiro-Wilk testi kullanılmışır. Bu test ile hesaplanan $p$ değerinin , 05 'ten büyük olması durumunda verilerin normal dağılımdan aşırı sapma göstermediği, küçük olması durumunda ise normal dağılım varsayımını karşılamadığı sonucuna ulaşılır (Büyüköztürk, 2013).

Verilerin normal dağılımı parametrik istatistiksel işlemleri; verilerin çarpık dağılımı ise parametrik olmayan istatistiksel işlemleri gerekli kılar (Büyüköztürk, 2013). Bu nedenle araştırmada normal dağılan veriler için ANOVA; normal dağılmayan veriler için Friedman testi kullanılmıştır. Düşük, orta ve yüksek seviyeli grupların Akşamla Gelen ve Tac Mahal Metni Okuduğunu Anlama Soruları'na verdiği cevaplardan elde edilen puanların normalliğine ilişkin test sonuçları aşă̆ıdaki tablolarda sunulmuştur:

Tablo 4.

Düşük Seviyeli Grupların Akşamla Gelen ve Tac Mahal Metni Okuduğunu Anlama Sorularından Elde Edilen Puanların Normalliğine Iliş̧kin Test Sonuçları

\begin{tabular}{lccc}
\hline & istatistik & $\begin{array}{c}\text { Shapiro-Wilk } \\
\text { Sd }\end{array}$ & $\mathrm{p}$ \\
\cline { 2 - 4 } Düşük grup 1 & & &, 632 \\
Akşamla Gelen &, 964 & 20 &, 306 \\
Tac Mahal &, 946 & 20 & \\
& & &, 165 \\
Düşük grup 2 &, 931 & 20 &, 029 \\
Akşamla Gelen &, 892 & 20 & \\
Tac Mahal & & & \\
Düşük grup 3 & & & \\
\hline
\end{tabular}




\begin{tabular}{llll}
\hline Akşamla Gelen &, 968 & 20 &, 721 \\
Tac Mahal &, 979 & 20 &, 917 \\
\hline
\end{tabular}

Düşük seviyeli grupların her üçü için de Akşamla Gelen Okuduğunu Anlama Soruları'ndan elde edilen puanlar normal dağılmaktadır ( $\mathrm{d} 1$ için $p=, 632$; $\mathrm{d} 2$ için $p=, 165$ ve $\mathrm{d} 3$ için $p=, 721$ ) ve varyanslar homojendir $(F=, 806 ; p=, 452)$. Varsayımların sağlanması ile bu üç grubun karşılaştırılmasında parametrik istatistiklerden varyans analizi (ANOVA) kullanılmıştır.

Düşük seviyeli gruplar için Tac Mahal Metni Okuduğunu Anlama Soruları'ndan elde edilen puanlar incelendiğinde puanların iki grupta normal dağıldığı fakat bir grupta normal dağılım göstermediği saptanmıştır ( $\mathrm{d} 1$ için $p=, 306$; $\mathrm{d} 2$ için $p=, 029$ ve $\mathrm{d} 3$ için $p=, 917$ ). Normallik varsayımının bütün gruplar için sağlanamaması nedeniyle bu üç grubun karşılaştırılmasında nonparametrik istatistiklerden Friedman testi kullanılmıştır.

Tablo 5.

Orta Seviyeli Grupların Akşamla Gelen ve Tac Mahal Metni Okuduğunu Anlama Sorularından Elde Edilen Verilerin Normalliğine IIlişkin Test Sonuçları

\begin{tabular}{lccc}
\hline & istatistik & Shapiro-Wilk & \\
\cline { 2 - 4 } Orta grup 1 & & sd & p \\
Akşamla Gelen &, 841 & 20 &, 004 \\
Tac Mahal &, 982 & 20 &, 952 \\
Orta grup 2 & & & \\
Akşamla Gelen &, 926 & 20 &, 128 \\
Tac Mahal &, 910 & 20 &, 063 \\
Orta grup 3 & & & \\
Akşamla Gelen &, 917 & 20 &, 087 \\
Tac Mahal &, 918 & 20 &, 091 \\
\hline
\end{tabular}

Orta seviyeli gruplar için Akşamla Gelen Metni Okuduğunu Anlama Soruları'ndan elde edilen puanlar incelendiğinde puanların iki grupta normal dağıldığı fakat bir grupta normal dağılım göstermediği saptanmıştır (o1 için $p=, 004$; 02 için $p=, 128$ ve o3 için $p=, 087$ ). Normallik varsayımının bütün gruplar için sağlanamaması nedeniyle bu üç grubun karşılaştırılmasında nonparametrik istatistiklerden Friedman testi kullanılmıştır.

Orta seviyeli grupların her üçü için de Tac Mahal Metni Okuduğunu Anlama Soruları'ndan elde edilen puanlar normal dağılmaktadır (o1 için $p=, 952$; o2 için $p=, 063$ ve o3 için $p=, 091$ ) ve varyanslar homojendir $(F=, 353 ; p=, 704)$. Varsayımların sağlanması ile bu üç grubun karşılaştırılmasında parametrik istatistiklerden varyans analizi (ANOVA) kullanılmıştır.

Tablo 6.

Yüksek Seviyeli Grupların Akşamla Gelen ve Tac Mahal Metni Okuduğunu Anlama Sorularından Elde Edilen Verilerin Normalliğine İlişkin Test Sonuçları

\begin{tabular}{lccc}
\hline & istatistik & Shapiro-Wilk & \\
\hline Yüksek grup 1 & & sd & \\
Akşamla Gelen &, 947 & 20 &, 325 \\
Tac Mahal &, 875 & 20 &, 015 \\
Yüksek grup 2 & & & \\
Akşamla Gelen &, 913 & 20 &, 073 \\
Tac Mahal &, 895 & 20 &, 033 \\
Yüksek grup 3 & & &, 343 \\
Akşamla Gelen &, 948 & 20 & \\
\hline
\end{tabular}




\begin{tabular}{llll}
\hline Tac Mahal & 901 & 20 &, 043
\end{tabular}

Yüksek seviyeli grupların her üçü için de Akşamla Gelen Okuduğunu Anlama Soruları'ndan elde edilen puanlar normal dağılmaktadır (y1 için $p=, 325$; y2 için $p=, 073$ ve y3 için $p=, 343$ ) ve varyanslar homojendir $(F=3,108 ; p=, 052)$. Varsayımların sağlanması ile bu üç grubun karşılaştırılmasında parametrik istatistiklerden varyans analizi ANOVA kullanılmıştır.

Yüksek seviyeli gruplar için Tac Mahal Metni Okuduğunu Anlama Soruları'ndan elde edilen puanlar incelendiğinde puanların her üç grupta normal dağılım göstermediği saptanmıştır ( $y 1$ için $p=, 015$; y2 için $p=, 033$ ve $y 3$ için $p=, 043$ ). Normallik varsayımının bütün gruplar için sağlanamaması nedeniyle bu üç grubun karşılaştırılmasında nonparametrik istatistiklerden Friedman testi kullanılmıştır.

\section{Bulgular}

\section{Araştırmanın Nicel Verilerinden Elde Edilen Bulgular}

Yüzey Yapısı Değiştirilmiş Metinler ile "Düşük" Seviyeli Öğrenci Gruplarının Okuduğunu Anlamaları Arasındaki iliş̧kiyle ilgili Bulgular

Düşük seviyeli grupların her üçü için de Akşamla Gelen Okuduğunu Anlama Soruları'ndan elde edilen normallik varsayımlarının sağlanması ile bu üç grubun karşılaştırılmasında parametrik istatistiklerden varyans analizi (ANOVA) kullanılmıştır.

Hikâye edici türde olan Akşamla Gelen metninin yüzey yapısı değiştirilmiş zor, orta ve kolay hâli ile "düşük" seviyeli öğrenci gruplarının (D1-D2-D3) okuduğunu anlamaları arasındaki ilişki Tablo 7 ve 8 'de verilmiştir:

Tablo 1.

Akşamla Gelen Metninin Düşük 1-2-3 Grubu İ̧̧in Betimsel Istatistikleri

\begin{tabular}{lccc}
\hline Metinler & $\mathrm{N}$ & $\bar{X}$ & SS \\
Zor metin & 20 & 9,40 & 4,10 \\
Orta metin & 20 & 12,00 & 4,60 \\
Kolay metin & 20 & 12,90 & 4,01 \\
Toplam & 60 & 11,43 & 4,43 \\
\hline
\end{tabular}

Tablo 2.

Akşamla Gelen Metninin Düşük Seviyeli Gruplar İçin ANOVA Sonuçları

\begin{tabular}{llcccc}
$\begin{array}{l}\text { Varyans } \\
\text { Kaynağı }\end{array}$ & $\begin{array}{c}\text { Kareler } \\
\text { Toplamı }\end{array}$ & sd & $\begin{array}{c}\text { Kareler } \\
\text { Ortalaması }\end{array}$ & F & $p$ \\
\cline { 1 - 4 } Gruplararası & 132,133 & 2 & 66,06 & & \multirow{2}{*}{032} \\
$\begin{array}{l}\text { Gruplariçi } \\
\text { Toplam }\end{array}$ & 1028,600 & 57 & 18,04 & 3,66 & \\
\hline
\end{tabular}

Tablo 7 ve 8 incelendiğinde Akşamla Gelen metninin "Düşük 1-2-3" grubu için varyans analizi sonuçlarına göre bu üç puan ortalamaları arasında anlamlı bir fark bulunmuştur $(F(2,57)=3,66, p=$ ,032). Farkın hangi gruplardan kaynaklandığına ilişkin yapılan ikili karşılaştırmalar, düşük grubun zor metinden elde ettikleri puanların $(\bar{X}=9,4)$, kolay metinden elde ettikleri puanlardan $(\bar{X}=12,9)$ anlamlı olarak daha düşük olduğunu göstermektedir.

Araştırmadan elde edilen bu bulgu, yüzey yapısı değiştirilmiş hikâye edici türde olan metinlerin, "düşük" okuma seviyesine sahip öğrencilerde metnin zor olan özgün hâline göre daha anlaşılır olduğunu göstermektedir.

Yüzey yapısı değiştirilmiş metinler ile "düşük" seviyeli öğrenci gruplarının (D1-D2-D3) okuduğunu anlamaları arasındaki ilişkiyi belirlemek amacıyla Tac Mahal Okuduğunu Anlama Soruları'ndan elde edilen normallik varsayımının bütün gruplar için sağlanamaması nedeniyle bu üç grubun karşılaştırılmasında nonparametrik istatistiklerden Friedman testi kullanılmıştır. 
Bilgilendirici türde olan Tac Mahal metninin yüzey yapısı değiştirilmiş zor, orta ve kolay hâli ile "düşük" seviyeli öğrenci gruplarının (D1-D2-D3) okuduğunu anlamaları arasındaki ilişki Tablo 9'da verilmiştir:

Tablo 3.

Tac Mahal Metninin Düşük Seviyeli Gruplar İ̧̧in Friedman Testi Sonuçları

\begin{tabular}{lccccc}
\hline Metinler & $\mathrm{n}$ & Sira ort. & Sd & $\chi^{2}$ & $p$ \\
\hline Zor metin & 20 & 1,45 & 2 & & \\
Orta metin & 20 & 2,25 & & & \multirow{2}{*}{007} \\
Kolay metin & 20 & 2,30 & & 973 & \\
Toplam & 60 & & & & \\
\hline
\end{tabular}

Tablo 9 incelendiğinde düşük seviyeli gruplar için Tac Mahal metninin zor, orta ve kolay değişimi ile elde edilen puanlar arasındaki farkın anlamlı olduğu görülmektedir $\left(\chi^{2}(s d=2, n=20)=\right.$ $9,973, p=, 007)$. Farkın hangi gruplardan kaynaklandığına ilişkin yapılan ikili karşılaştırmalar, zor metinden elde edilen puanlara ilişkin sıra ortalamalarının (sıra ort.: 1,45), kolay metinden elde edilen puanlardan (sıra ort.: 2,30) anlamlı olarak daha düşük olduğunu göstermektedir.

Araştırmadan elde edilen bu bulgu, yüzey yapısı değiştirilmiş bilgilendirici türde olan metinlerin, "düşük" okuma seviyesine sahip öğrencilerde metnin zor olan özgün hâline göre daha anlaşılır olduğunu göstermektedir.

\section{Yüzey Yapısı Değiştirilmiş Metinler ile "Orta" Seviyeli Öğrenci Gruplarının Okuduğunu Anlamaları Arasındaki iliş̧kiyle ilgili Bulgular}

Yüzey yapısı değiştirilmiş metinler ile "orta" seviyeli öğrenci gruplarının (D1-D2-D3) okuduğunu anlamaları arasındaki ilişkiyi belirlemek amacıyla Akşamla Gelen Okuduğunu Anlama Soruları'ndan elde edilen normallik varsayımının bütün gruplar için sağlanamaması nedeniyle bu üç grubun karşılaştırılmasında nonparametrik istatistiklerden Friedman testi kullanılmıştır.

Hikâye edici türde olan Akşamla Gelen metninin yüzey yapısı değiştirilmiş zor, orta ve kolay hâli ile "orta" seviyeli öğrenci gruplarının (O1-O2-O3) okuduğunu anlamaları arasındaki ilişki Tablo 10'da verilmiştir:

Tablo 10.

\begin{tabular}{lccccc}
\multicolumn{6}{l}{ Akşamla Gelen Metninin Orta Seviyeli Gruplar } \\
\hline Meticin Friedman Testi Sonuçları & $\mathrm{n}$ & Sıra ort. & Sd & $\chi^{2}$ & $p$ \\
\hline Zor metin & 20 & 1,50 & 2 & & \\
Orta metin & 20 & 1,98 & & & \\
Kolay metin & 20 & 2,53 & & 10,658 &, 005 \\
Toplam & 60 & & & & \\
\hline
\end{tabular}

Tablo 10'a göre orta seviyeli gruplar için Akşamla Gelen metninin zor, orta ve kolay değişimi ile elde edilen puanlar arasındaki farkın anlamlı olduğu görülmektedir $\left(\chi^{2}(s d=2, n=20)=10,658, p=\right.$ ,005). Farkın hangi gruplardan kaynaklandığına ilişkin yapılan ikili karşılaştırmalar, zor metinden elde edilen puanlara ilişkin sıra ortalamalarının (sıra ort.: 1,50), kolay metinden elde edilen puanlardan (sıra ort.: 2,53) anlamlı olarak daha düşük olduğunu göstermektedir.

Bu bulguya göre, yüzey yapısı değiştirilmiş hikâye edici türde olan metinlerin, "orta" okuma seviyesine sahip öğrencilerde metnin zor olan özgün hâline göre daha anlaşılır olduğu görülmektedir.

Orta seviyeli grupların her üçü için de Tac Mahal Okuduğunu Anlama Soruları'ndan elde edilen normallik varsayımlarının sağlanması ile bu üç grubun karşılaştırılmasında parametrik istatistiklerden varyans analizi (ANOVA) kullanılmıştır. 
Bilgilendirici türde olan Tac Mahal metninin yüzey yapısı değiştirilmiş zor, orta ve kolay hâli ile "orta" seviyeli öğrenci gruplarının (01-02-03) okuduğunu anlamaları arasındaki ilişki Tablo 11 ve 12 'de verilmiştir:

Tablo 4.

Tac Mahal Metninin Orta 1-2-3 Grubu İçin Betimsel Istatistikleri

\begin{tabular}{|c|c|c|c|}
\hline Metinler & $n$ & & SS \\
\hline Zor metin & 20 & 15,55 & ,79 \\
\hline Orta metin & 20 & 15,75 & 79 \\
\hline Kolay metin & 20 & 18,75 & 86 \\
\hline Toplam & 60 & 16,68 & 50 \\
\hline
\end{tabular}

Tablo 5. Tac Mahal Metninin Orta Seviyeli Gruplar Için ANOVA Sonuçları

\begin{tabular}{|c|c|c|c|c|c|}
\hline Varyans Kaynağı & $\begin{array}{l}\text { Kareler } \\
\text { Toplamı }\end{array}$ & sd & $\begin{array}{c}\text { Kareler } \\
\text { Ortalaması }\end{array}$ & $\mathrm{F}$ & $p$ \\
\hline Gruplararası & 128,533 & 2 & 64,267 & & \\
\hline Gruplariçi & 766,450 & 57 & 13,446 & 4,779 & 012 \\
\hline Toplam & 894,983 & 59 & & & \\
\hline
\end{tabular}

Tablo 11 ve 12'ye göre Tac Mahal metninin "Orta 1-2-3" grubu için varyans analizi sonuçlarına göre bu üç puan ortalamaları arasında anlamlı bir fark bulunmuştur $(\mathrm{F}(2,57)=4,779, p=$ ,012). Farkın hangi gruplardan kaynaklandığına ilişkin yapılan ikili karşılaştırmalar, düşük grubun zor metinden elde ettikleri puanların $(\bar{X}=15,5)$, kolay metinden elde ettikleri puanlardan $(\bar{X}=18,7)$ anlamlı olarak daha düşük olduğunu göstermektedir.

Bu bulguya göre, yüzey yapısı değiştirilmiş bilgilendirici türde olan metinlerin, "orta" okuma seviyesine sahip öğrencilerde metnin zor olan özgün hâline göre daha anlaşılır olduğu görülmektedir.

\section{Yüzey Yapısı Değiştirilmiş Metinler ile "Yüksek" Seviyeli Öğrenci Gruplarının Okuduğunu Anlamaları Arasındaki ilişskiyle ilgili Bulgular}

Yüksek seviyeli grupların her üçü için de Akşamla Okuduğunu Anlama Soruları'ndan elde edilen normallik varsayımlarının sağlanması ile bu üç grubun karşılaştırılmasında parametrik istatistiklerden varyans analizi (ANOVA) kullanılmıştır.

Hikâye edici türde olan Akşamla Gelen metninin yüzey yapısı değiştirilmiş zor, orta ve kolay hâli ile "yüksek" seviyeli öğrenci gruplarının (Y1-Y2-Y3) okuduğunu anlamaları arasındaki ilişki Tablo 13 ve 14 'te verilmiştir:

Tablo 6.

Akşamla Gelen Metninin Yüksek 1-2-3 Grubu Için Betimsel Istatistikleri

\begin{tabular}{llcc}
\hline Metinler & $\mathrm{N}$ & $\bar{X}$ & SS \\
\hline Zor metin & 20 & 20,40 & 4,13 \\
Orta metin & 20 & 21,35 & 5,55 \\
Kolay metin & 20 & 22,85 & 3,49 \\
Toplam & 60 & 21,53 & 4,51 \\
\hline
\end{tabular}

Tablo 14.

Akşamla Gelen Metninin Yüksek Seviyeli Gruplar İçin ANOVA Sonuçları

\begin{tabular}{lccccc}
$\begin{array}{l}\text { Varyans } \\
\text { Kaynağı }\end{array}$ & $\begin{array}{c}\text { Kareler } \\
\text { Toplamı }\end{array}$ & sd & $\begin{array}{c}\text { Kareler } \\
\text { Ortalaması }\end{array}$ & F & $P$ \\
\cline { 1 - 4 } Gruplararası & 61,033 & 2 & 30,517 & & \\
\cline { 1 - 4 } Gruplariçi & 1143,900 & 57 & 20,068 & 1,521 & \multirow{2}{*}{227} \\
\hline
\end{tabular}




\begin{tabular}{lll}
\hline Toplam & 1204,933 & 59 \\
\hline
\end{tabular}

Tablo 13 ve 14 incelendiğinde Akşamla Gelen metninin "Yüksek 1-2-3" grubu için varyans analizi sonuçlarına göre bu üç puan ortalamaları arasında anlamlı bir fark bulunmadığı görülmektedir $(F(2,57)=1,521, p=, 227)$.

Bu bulgu, yüzey yapısı değiştirilmiş hikâye edici türde olan metinlerin, "yüksek" okuma seviyesine sahip öğrencilerde metnin zor olan özgün hâline göre anlaşlırlık düzeyinin değişmediğini göstermektedir.

Yüzey yapısı değiştirilmiş metinler ile "yüksek" seviyeli öğrenci gruplarının (Y1-Y2-Y3) okuduğunu anlamaları arasındaki ilişkiyi belirlemek amacıyla Tac Mahal Okuduğunu Anlama Soruları'ndan elde edilen normallik varsayımının bütün gruplar için sağlanamaması nedeniyle bu üç grubun karşılaştırılmasında nonparametrik istatistiklerden Friedman testi kullanılmıştır.

Bilgilendirici türde olan Tac Mahal metninin yüzey yapısı değiştirilmiş zor, orta ve kolay hâli ile "yüksek" seviyeli öğrenci gruplarının (Y1-Y2-Y3) okuduğunu anlamaları arasındaki ilişki Tablo 15'te verilmiştir:

Tablo 7.

Tac Mahal Metninin Yüksek Seviyeli Gruplar Için Fridman Testi Sonuçları

\begin{tabular}{lccccc}
\hline Metinler & $\mathrm{N}$ & Sira ort. & Sd & $\chi^{2}$ & $\mathrm{p}$ \\
\hline Zor metin & 20 & 1,30 & 2 & & \\
Orta metin & 20 & 2,15 & & & \\
Kolay metin & 20 & 2,55 & & 17,38 &, 000 \\
Toplam & 60 & & & \\
\hline
\end{tabular}

Tablo 15'e göre yüksek seviyeli gruplar için Tac Mahal metninin zor, orta ve kolay değişimi ile elde edilen puanlar arasındaki farkın anlamlı olduğu görülmektedir $\left(\chi^{2}(s d=2, n=20)=17,387, p=, 000\right)$. Farkın hangi gruplardan kaynaklandı̆̆ına ilişkin yapılan ikili karşılaştırmalar, zor metinden elde edilen puanlara ilişkin sıra ortalamalarının (sıra ort.: 1,30 ), kolay metinden elde edilen puanlardan (sıra ort.: 2,55 ) anlamlı olarak daha düşük olduğunu göstermektedir.

Bu bulguya göre, yüzey yapısı değiştirilmiş bilgilendirici türde olan metinlerin, "yüksek" okuma seviyesine sahip öğrencilerde metnin zor olan özgün hâline göre daha anlaşlır olduğu görülmektedir.

\section{Araştırmanın Nitel Verilerinden Elde Edilen Bulgular}

Metinler Üzerinde Yapılan Değişimler İ̧̧in Öğrenci Görüşme Formuyla Elde Edilen Bulgular

Metinler üzerinde "ekleme, çıkarma, değiştirme, yer değiştirme, bölme ve birleştirme" işlemleri yapılmıştır. Araştırmanın bu bölümünde Metinler Üzerinde Yapılan Değişimler İ̧̧in Öğrenci Görüşme Formu ile bu işlemlere ait öğrenci işaretlemelerine yönelik bulgular sunulmuştur.

Tablo 16.

Akşamla Gelen Metni Işslemleri İ̧in Öğrenci Cevapları

\begin{tabular}{|c|c|c|c|c|c|c|}
\hline & Ekleme & Çıkarma & Değiştirme & $\begin{array}{l}\text { Yer } \\
\text { değiştirme }\end{array}$ & Bölme & Birleştirme \\
\hline Özgün cümle & 15,66 & 10,46 & 6,97 & 10,23 & 23,58 & 12,06 \\
\hline Değişen cümle & 83,33 & 89,53 & 93,02 & 89,76 & 76,41 & 87,93 \\
\hline \multicolumn{7}{|c|}{ Tablo 17. Tac Mahal Metni İşlemleri Iç̧in Öğrenci Cevapları } \\
\hline & Ekleme & Çıkarma & Değiştirme & $\begin{array}{l}\text { Yer } \\
\text { değiştirme }\end{array}$ & Bölme & Birleştirme \\
\hline Özgün cümle & 8,92 & 10,46 & 11,24 & - & 11,70 & 35,55 \\
\hline Değişen cümle & 91,07 & 89,53 & 88,75 & - & 88,29 & 64,44 \\
\hline
\end{tabular}


Tablo 16 ve 17 incelendiğinde Akşamla Gelen ve Tac Mahal metni ekleme, çıkarma, değitirme, yer değiştirme, bölme, birleştirme işlemleri için öğrencilerin çoğunluğunun özgün cümlelere oranla değişen cümleleri tercih etmek için işaretledikleri görülmektedir.

\section{Görüşme Formuyla Elde Edilen Öğrenci Cevaplarıyla İlgili Bulgular}

Öğrencilerin yüzey yapı değişiklikleri ile ilgili görüşleri önce tercih ettikleri cümleler düzeyinde, sonra tercih ettikleri cümlelerin nedenini ifade ettikleri açılamalar düzeyinde incelenmiştir. Öğrencilerin yüzey yapı değişiklikleri ile ilgili görüşler kodlanıp kategoriler altında toplanmıştır. Öğrenci görüşleri aktarılırken birbirinin aynısı olan ifadelere yer verilmemiştir.

Öğrencilerin değişen cümleler için görüşleri aşağıdaki ifadelerle dile getirilmiştir:

1. Öğrencilerin yüzey yapı değiştirme işlemlerinden ekleme işlemine yönelik görüşleri şöyledir:

(Ö1): "Birleşik olduğu için daha kısa anlaşılır."

(Ö2): "Türkçe kelimeler kullanılmış."

(Ö3): "Cümlenin nasıl bittiği belli olduğu için daha anlamlı."

(Ö4): "Üç nokta kullanılması anlam bozukluğu yapıyor."

(Ö5): "Yüklem olduğu için cümle tamamlanmış ve bu nedenle daha anlaşılır."

(Ö6): "Diğer cümlede (özgün cümle) anlam bozukluğu var."

Öğrencilerin bu cümlelere ilişkin görüşlerinde "daha anlaşılır olma, daha kolay okunma, anlatım bozukluğunun anlam üzerindeki olumsuz etkisini ortadan kaldırma, akıcılık" kodlarına ulaşılmıştır.

2. Öğrencilerin yüzey yapı değiştirme işlemlerinden çıkarma işlemine yönelik görüşleri şöyledir:

(Ö1): "Beyitit anlamadığım için bu cümle (değişen cümle) daha uygun."

(Ö2): "Daha sadeleştirilmiş olduğu için bu cümle daha anlaşılır."

(Ö3): "Bu beyit bize göre fazla olduğu için bu cümleyi (değişen cümle) seçiyorum."

(Ö4): "Diğer cümlede (özgün cümle) anlaşılmayan eski kelimeler var."

Öğrencilerin bu cümlelere ilişkin görüşlerinde "yabancı sözcüklerin anlam üzerindeki olumsuz etkisini ortadan kaldırma, Türkçe sözcüklerle anlama olumlu katkı sağlama, günlük hayatta kullanılan ifadelerle anlama katkı sağlama" kodlarına ulaşılmıştır. şöyledir:

3. Öğrencilerin yüzey yapı değiştirme işlemlerinden değiştirme işlemine yönelik görüşleri

(Ö1): "Diğer cümlede yabancı kelime kullanıldığı için bu cümle (değişen cümle) daha anlaşılır."

(Ö2): "Kelimeler bu cümlede daha anlaşılır kullanılmıştır."

(Ö3): "Türkçe kelimeler daha anlaşılır."

(Ö4): "Lady yerine hanımefendi kullanılması daha anlamlı."

Öğrencilerin bu cümlelere ilişkin görüşlerinde "Bilinmeyen sözcüklerin anlam üzerindeki olumsuz etkisini ortadan kaldırma, daha anlaşılır olmayı sağlama" kodlarına ulaşılmıştır.

4. Öğrencilerin yüzey yapı değiştirme işlemlerinden yer değiştirme işlemine yönelik görüşleri şöyledir:

(Ö1): "Kelimeler daha doğru kullanılmıştır."

(Ö2): Kurabiye soyup soyup yenecek bir yiyecek olmadığı için birinci cümle (özgün cümle) hatalıdır. ${ }^{\neq \prime \prime}$

(Ö3): "Şehrin nerede olduğunu da açıklamış daha anlaşılır."

(Ö4): "Bilmediğimiz kelimeler anlamamızı zorlaştırıyor."

\footnotetext{
+ Öğrencilerin bahsettiği beyit Tac Mahal metninde geçen şu beyittir:

“Merkad-i münevver-i Ercümend Bânû

Bîgüm Muhatab be-mümtaz-ı Mahal"

‡ Öğrencinin bahsettiği cümle Akşamla Gelen metninde geçen şu cümledir: "Malları ya baklavadır ya kadayıftır ya soyup soyup yenecek muzdur, kurabiyedir."
} 
Öğrencilerin bu maddeye ilişkin görüşlerinde "daha kolay okunma, anlatım bozukluğunun anlam üzerindeki olumsuz etkisini ortadan kaldırma, değişen cümlelerin okuma tutumuna olumlu etkisini sağlama" kodlarına ulaşılmıştır.

5. Öğrencilerin yüzey yapı değiştirme işlemlerinden bölme işlemine yönelik görüşleri şöyledir:

(Ö1): "Bu cümle (değişen cümle) 2'ye bölünmüş daha anlamlı bu yüzden diğerine (özgün cümle) göre daha anlamlı."

(Ö2): "Uzun cümleler yorucu olduğu için bu cümle (değişen cümle) daha iyi."

(Ö3): "Noktalama işareti olduğu için bu cümle (değişen cümle) daha kolay."

(Ö4): "Daha çok cümleden oluştuğu için bu cümleler daha anlaşılır."

Öğrencilerin bu cümlelere ilişkin görüşlerinde "noktalama işaretlerinin anlam üzerindeki etkisini arttırma, uzun cümlelerin okuma tutumu üzerindeki olumsuz etkisini ortadan kaldırma" kodlarına ulaşılmıştır. şöyledir:

6. Öğrencilerin yüzey yapı değiştirme işlemlerinden birleştirme işlemine yönelik görüşleri

(Ö1): "Bir cümle virgül kullanarak tek cümle yapılmış bu yüzden daha anlaşılır."

(Ö2): "Yüklem olduğu için daha anlamlı geliyor."

(Ö3): "Üç nokta yerine virgül kullanılması daha iyi."

(Ö4): "Diğer (özgün cümle) cümle farklı anlama yol açabilir."

(Ö5): "Diğer cümle (özgün cümle) bitmediği için anlaşılmıyor."

(Ö6): "Diğer cümle (özgün cümle) farklı anlama yol açabilir"

Öğrencilerin bu maddeye ilişkin görüşlerinde "eksiltili yapıların anlam üzerine olumsuz etkisini ortadan kaldırma, tamamlanmış/bitmiş/sonlanmış cümleler ile anlama olumlu katkı sağlama" kodlarına ulaşılmıştır.

Öğrencilerin özgün cümleler için görüşleri aşağıdaki ifadelerle dile getirilmiştir:

(Ö1): "Bu cümle daha uzun ve açıklayıcı."

(Ö2): "Böylesi daha çok hoşuma gittiği için daha güzel."

(Ö3): "Bilmediğimiz şeyleri araştırırsak daha iyi olur."

(Ö4): "Lady kelimesi daha havalı."

Öğrencilerin bu maddeye ilişkin görüşlerinde "bilinmeyen sözcükleri araştırmaya teşvik etmesi, hoşa gitmesi "kodlarına ulaşılmıştır.

Öğrencilerin Metinler Üzerinde Yapılan Değişimler İçin Öğrenci Görüşme Formu'na verdikleri cevaplarda 16 ayrı kod tespit edilmiştir. Elde edilen kodların genellenmesiyle ulaşılan kategoriler aşağıdaki tabloda sunulmuştur:

Tablo 18.

Yüzey Yapısı Değişstirilmiş Cümleler İ̧̧in Öğrenci Görüşlerinden Elde Edilen Kategoriler ve Kodlar

\begin{tabular}{ll}
\hline Kategoriler & Kodlar \\
\hline Okumaya karşı olumlu tutum & Uzun cümlelerin okuma tutumu üzerindeki olumsuz \\
& etkisini ortadan kaldırabilme \\
& Değişen cümlelerin okuma tutumuna olumlu etkisini \\
& sağlayabilme \\
\hline Cümlenin anlamına katkısı & Daha anlaşılır olma \\
& Daha kolay okunma \\
& Anlatım bozukluğunun anlam üzerindeki olumsuz \\
& etkisini ortadan kaldırabilme \\
& Akıcılık \\
\hline Sözcük seçimine etkisi & Yabancı sözcüklerin anlam üzerindeki olumsuz etkisini \\
& ortadan kaldırabilme \\
& Türkçe sözcüklerle anlama olumlu katkı sağlayabilme \\
& Günlük hayatta kullanılan ifadelerle anlama katkı \\
sağlayabilme
\end{tabular}


Noktalama işaretleri ve cümle yapılarının Noktalama işaretlerinin anlam üzerindeki etkisini anlama katkısı

arttırabilme

Eksiltili yapıların anlam üzerine olumsuz etkisini ortadan kaldırabilme

Tamamlanmış/bitmiş/sonlanmış cümleler ile anlama olumlu katkı sağlayabilme

Bilinmeyen sözcüklerin anlam üzerindeki Bilinmeyen sözcüklerin anlam üzerindeki olumsuz etkisi etkisini ortadan kaldırabilme Daha anlaşılır olmayı sağlayabilme

Özgün cümleleri tercih etme nedenleri Bilinmeyen sözcüklerin araştırmaya teşvik etmesi Hoşa gitmesi

\section{Kelime Değiştirme iş̧leminden Elde Edilen Bulgular}

Araştırmada öğrenciler, Akşamla Gelen ve Tac Mahal metinlerinde anlamını bilmedikleri kelimeleri tespit etmişlerdir. Öğrencilerin tespit ettikleri bu kelimeler araştırmacı tarafından değiştirilmiştir. Kelime düzeyinde yapılan bu değişimlerin yer aldığı metinler toplam 427 . sınıf öğrencisine tekrar okutularak metinlerde anlamını bilmedikleri kelimeleri işaretlemeleri istenmiştir. Bu uygulama sonucunda öğrencilerin anlamını bilmedikleri kelimeler yerine kullanılan kelimeleri tercih etme yüzdeleri hesaplanmıştır. Bu uygulamadan elde edilen bulgular aşağıdaki tablolarda sunulmuştur.

Akşamla Gelen metni kelime değiştirme işlemi için öğrenci cevapları aşağıdaki tabloda gösterilmiştir:

Tablo 19.

Akşamla Gelen Metni Kelime Değiştirme İşlemi Iç̧in Öğrenci Cevapları

\begin{tabular}{ccc}
\hline Özgün kelime & Değişen kelime & Değişen kelime için işaretleme \\
\hline Yahut & Ya da & 0 \\
Pikap & Müzikçalar & 0 \\
Sükûnet & Huzur & 0 \\
Cemiyet & Birlikte & 0 \\
Tecessüm & Belirip & 0 \\
Haz & Sevinç & 0 \\
Hazmetmek & Sindirmek & 0 \\
Hüviyet & Kimlik & 0 \\
Teyp & Radyo & 0 \\
Ziyadeleşmek & Çoğalmak & 0 \\
\hline
\end{tabular}

Tablo 19 incelendiğinde Akşamla Gelen metninde kullanılan özgün kelimeler yerine değiştirilen kelimelerin 42 öğrenci tarafından hiç işaretlenmediği görülmektedir. Bu sonuca göre, değiştirilen kelimelerin anlamlarını öğrencilerin tamamının bildiği görülmektedir.

Tablo 20.

Tac Mahal Metni Kelime Değiştirme Işslemi İçin Öğrenci Cevapları

\begin{tabular}{ccc}
\hline Özgün kelime & Değişen kelime & Değişen kelime için işaretleme \\
\hline Müşahede & Gözlem & 0 \\
Latif & Hoş & 0 \\
Muntazam & Kusursuz & 0 \\
Nefaset & Değer & 0 \\
Misyoner & Din görevlisi & 0 \\
\hline
\end{tabular}




\begin{tabular}{ccc}
\hline Aksettirmek & Yansıtmak & 0 \\
Sanduka & Mezar sandığı & 0 \\
Ketum & Gizleyen & 0 \\
Sülüs & Özel süslemeli & 0 \\
Yekpare & Tek parça & 0 \\
Tezyinat & Süsleme & 0 \\
\hline
\end{tabular}

Tablo 20 incelendiğinde Tac Mahal metninde kullanılan özgün kelimeler yerine değiştirilen kelimelerin 42 öğrenci tarafından hiç işaretlenmediği görülmektedir. Bu sonuç, değiştirilen kelimelerin anlamlarını öğrencilerin tamamının bildiğini göstermektedir.

\section{Tartışma, Sonuç ve Öneriler}

Ateşman Okunabilirlik Formülü'nden elde edilen hesaplamalara göre metinlerin özgün hâllerinin "zor" okunabilirlik düzeyine, yüzey yapısı değiştirilen metinlerin "orta" okunabilirlik düzeyine sahip olduğu görülmektedir. Araştırmadan elde edilen bulgular neticesinde, yüzey yapısı değiştirilmiş metinlerin daha kolay okunabilirlik seviyelerine getirilmeleri ile öğrencilerin okuduğunu anlama becerileri arasında olumlu yönde bir ilişkinin olduğu tespit edilmiştir.

Hikâye edici türde olan Akşamla Gelen metninin "Düşük 1-2-3 ve Orta 1-2-3" grubu analiz sonuçlarına göre okuduğunu anlama puan ortalamaları arasında anlamlı bir fark olduğu görülmektedir. Bu sonuca göre, düşük ve orta okuma başarısına sahip öğrenciler için yüzey yapısı değiştirilen kolay ve orta düzeyde olan metinlerin, metnin özgün hâli olan zor metne göre daha anlaşılır olduğu tespit edilmiştir. Akşamla Gelen metninin "Yüksek 1-2-3" grubu analiz sonuçlarına göre okuduğunu anlama puan ortalamaları arasında anlamlı bir fark olmadığı görülmektedir. Bu sonuca göre, yüksek okuma başarısına sahip öğrenciler için kolay, orta ve zor düzeyde olan metinlerin anlaşılma düzeyinin değişmediği tespit edilmiştir.

Bilgilendirici türde olan Tac Mahal metninin “Düşük 1-2-3, Orta 1-2-3 ve Yüksek 1-2-3" grubu analiz sonuçlarına göre okuduğunu anlama puan ortalamaları arasında anlamlı bir fark olduğu görülmektedir. Bu sonuca göre, düşük, orta ve yüksek okuma başarısına sahip öğrenciler için yüzey yapısı değiştirilen kolay ve orta düzeyde olan metinlerin, metnin özgün hâli olan zor metne göre daha anlaşılır olduğu tespit edilmiştir.

Araştırmadan elde edilen bu sonuçlara göre düşük ve orta okuma başarısına sahip öğrencilerin hikâye edici metin türünde okuma başarı puanlarında anlamlı bir fark görülürken; yüksek okuma başarısına sahip öğrencilerin okuma başarı puanlarında anlamlı bir fark görülmemiştir. Bilgilendirici metin türünde ise öğrenci seviyelerinin tamamının okuma başarı puanlarında anlamlı bir fark olduğu tespit edilmiştir. Bu sonuç, yüzey yapı değişikliklerinin bilgilendirici metin türünde daha işlevsel olduğunu ortaya koymaktadır.

Araştırmaya katılan öğrencilerin Metinler Üzerinde Yapılan Değişimler İçin Öğrenci Görüşme Formu'na verdikleri cevaplar değerlendirildiğinde, öğrencilerin çoğunluğunun metinler üzerinde yapılan değişimler için olumlu yönde görüş belirttikleri sonucuna ulaşılmıştır. Öğrenciler yüzey yapısı değiştirilmiş metinlerde geçen kelimelerin ve cümlelerin daha iyi anlaşıldığını; yüzey yapısı değiştirilmemiş özgün metinlerde geçen kelimelerin ve cümlelerin daha zor anlaşıldığını ifade etmişlerdir.

Araştırmanın nicel ve nitel verilerinden elde edilen sonuçlara göre, metinlerde anlamı bilinmeyen sözcüklerin sıklığı, yabancı sözcükler, anlatım bozuklukları, uzun cümle yapıları, eksiltili ifadeler gibi yapılar anlam kurmayı zorlaştırmaktadır. Araştırmaya göre, bu yapılar dikkate alınarak yapılan değişimlerin öğrencilerin daha kolay anlam kurmalarına yardımcı olduğu sonucuna ulaşıııışıtır.

Araştırmanın bulgularından elde edilen bu sonuçlara göre, bilgilendirici ve hikâye edici türden metinlerin zorluk dereceleri ile öğrencilerin okuduğunu anlama becerileri arasında anlamlı bir ilişki olduğu görülmektedir. Bu sonuçlar, öğrencilerin anlamakta zorluk çektikleri metinler üzerinde yapılan yüzey yapı değişikliklerinin anlamın daha kolay kurulmasına katkı sağladığını göstermiştir. 
Bu araştırmada, yüzey yapı değişiklikleri ile öğrencilerin okuduğunu anlama becerileri arasındaki ilişki incelenmiştir. Araştırmanın bu amacına ilişkin sonuçları, ilgili literatürde, Kökçü’nün (2018) deneysel desende metnin küçük yapı düzeyinde yapılan değişikliklerin öğrencilerin okuduğunu anlama becerilerine olan etkisini belirlemek amacıyla yaptığı çalışma sonucuyla benzerlik göstermektedir. Bu araştırmanın sonuçları ile olan benzerlik, metnin yüzey yapı değişiklerinin öğrencilerin okuduğunu anlama becerilerine olumlu yönde katkısı olduğunu göstermektedir.

Metinler Üzerinde Yapılan Değişimler İçin Öğrenci Görüşme Formu'yla elde edilen bulgular incelendiğinde ekleme, çıkarma, bölme, birleştirme, değiştirme ve yer değiştirme işlemleri için öğrencilerin özgün cümleye oranla daha çok değişen cümleyi tercih ettikleri görülmektedir. Bu sonuç öğrencilerin yüzey yapı değişliklerine karşı olumlu yönde görüş bildirdiklerini göstermektedir. Araştırmanın öğrenci görüşleri ile ilgili bu sonucu konuyla ilgili İskender ve Yiğit (2015) tarafından yapılan küçük yapı düzeyindeki değişimlerin öğrencilerin metni anlamalarına ilişkin görüşleri üzerine etkisini tespit ettikleri araştırma sonuçları ile benzerlik göstermektedir. Bu araştırma ve i̇skender ve Yiğit (2015) tarafından yapılan araştırma sonuçlarına göre, öğrenciler metinler üzerinde yapılan yüzey yapı değişikliklerine karşı olumlu yönde görüş bildirmişlerdir.

Öğrencilerin yüzey yapı değişikliklerine ilişkin bu olumlu görüşleri, araştırmanın nicel verileri ile elde edilen bulgularıyla da örtüşmektedir. Aynı zamanda, farklı veri toplama araçlarından elde edilen bu bulgular, yüzey yapı değişiklikleri ile öğrencilerin okuduğunu anlama becerileri arasında anlamlı bir ilişki olduğu sonucunun güvenilir olduğunu ortaya koymaktadır. Ancak literatürde yüzey yapı değişiklikleri ile öğrencilerin okuduğunu anlama becerileri arasındaki ilişkiyi tespit eden hem nitel hem de nicel verilerin birlikte kullanıldı̆̆ı bir araştırmaya rastlanmamıştır.

İlgili literatür incelendiğinde metinlerin okunabilirlik düzeylerini ölçen araştırmaların yapıldığı görülmektedir (Zorbaz, 2007; Çiftçi, Çeçen ve Melanlıŏlu, 2007; Okur ve Arı, 2013; Baş ve Yıldız, 2015). Bu araştırmalardan elde edilen sonuçlara göre ders kitaplarına seçilen metinlerin okunabilirlik düzeyleri açısından dengeli bir dağılım göstermediği, sınıf düzeyleri arasında metinlerin zorluk derecelerinde önemli farklar olduğu dikkati çekmektedir. Bu çalışmada veri toplama aracı olarak Türkçe ders kitaplarından seçilen hikâye edici ve bilgilendirici türde olan metinlerin özgün hâllerinin okunabilirlik seviyeleri "zor" olarak ölçülmüştür. Bu durum, metinlerin okunabilirlik seviyeleri ile öğrencilerin okuduğunu anlamaları arasında nasıl bir ilişki olduğunu ortaya koyan çalışmaların intiyacını ortaya koymaktadır.

Durukan'ın (2014) yaptığı araştırmaya göre, Türkçe ders kitaplarındaki metinlerin okunabilirlik düzeyleri ile öğrencilerin bu metinleri okuma hızı ve anlama oranları arasında anlamlı bir ilişki olduğu sonucuna ulaşılmıştır. Metinlerin okunabilirlikleri kolaydan zora doğru değiştikçe öğrencilerin okuduğunu anlama düzeyinde azalış görülmektedir. Bu azalış istatistiksel olarak anlamlı bir farklılık oluşturmaktadır. Buna göre, metinlerin kelime ve cümle uzunluklarının öğrencilerin okuma hızlarını ve okuduğunu anlama düzeylerini olumsuz etkilediğini göstermektedir.

Durukan'ın (2014) araştırma sonuçlarına benzer bir şekilde bu çalışmada da okunabilirlik seviyesi daha kolay olan metinler ile öğrencilerin okuduğunu anlama becerileri arasında anlamlı bir ilişki olduğu sonucuna ulaşılmıştır. Dolayısıyla okunabilirlik ile ilgili araştırmalar, metinlerin zorluk derecelerinin öğrencilerin anlam kurmaları üzerinde etkili olduğunu göstermektedir. Bu araştırmalardan elde edilen sonuçlar, öğrencilerin okuma ve anlama becerilerini geliştirebilmek için onların okuma seviyelerine uygun kitapların ya da metinlerin seçilmesine ihtiyaç duyulduğunu göstermektedir.

Geçmiş yıllarda hazırlanan Türkçe ders kitaplarına seçilen metinlerin düzenlenmesinde sadeleştirme çalışmalarının yapıldığı görülmektedir. Bayraktar ve Durukan'ın (2016) yaptıkları araştırmada Türkçe ders kitabında yer alan ve Ahmet Haşim tarafından yazılan Caddeler metninin özgün ve ders kitabında bulunan sadeleştirilmiş hâlini karşılaştırmışlardır. Bu araştırmanın sonuçlarına göre özgün metin ve sadeleştirilmiş metin arasında okunabilirlik düzeyleri, cümle yapıları ile kelime ve cümle sayıları arasında önemli farklar görülmezken; kelime ve kelime grubu üzerinde yapılan sadeleştirme çalışmalarında ise anlam farklılaşmasına neden olan değişimler olduğu saptanmıştır. Ancak metin düzenleme çalışmalarında metinlerin anlamında değişiklik olması istenen bir durum değildir. Türkçenin tarihî dönemlerinde yazıımış metinlerin çağdaş okurlar tarafından anlaşııması için 
anlamı değiştirmeden yüzey yapıda değişimlerin yapılması beklenir. Bu nedenle, eski dönemlerde yazılmış tarihi metinleri düzenlenme çalışmalarında uzmanların araştırmaları ve görüşleri dikkate alınmalıdır.

Illgili literatür incelendiğinde ana dili derslerinde kullanılan metinler üzerinde yapılan değiştirme işlemleri ile okuduğunu anlama becerileri arasındaki ilişkiyi ölçen çalışmaların kısıtı bir düzeyde olduğu görülmektedir. Literatürde yapılan araştırmaların daha çok yabancı dil öğrenicilerine yönelik olduğu görülmektedir. Yabancı dil öğrenicileri için yapılan betimsel çalışmalarda, metinler üzerinde yapılacak değişimlerin yabancı dil öğrenicilerinin okuduğunu anlama becerilerini geliştireceği öngörülmektedir (Bakan, 2012; Durmuş, 2013a; 2013b).

Yabancı dil öğrenicilerinin okuduğunu anlama becerilerinin geliştirilmesinde metinler üzerinde yapılan değişimleri ele alan ve betimsel çalışmaların sonuçlarını destekleyen deneysel araştırmalar da yapıımıştır. Yabancı dil öğrenicileri için yapılan deneysel çalışmalarda, bu araştırma sonuçlarına benzer şekilde, metin üzerinde yapılan değişimlerin yabancı dil öğrenicilerinin okuduğunu anlama becerilerini geliştirdiği sonuçlarına ulaşıımıştır (Maxvell, 2011; Li, Xu S. ve Wang, 2005; Oh, 2001; Yano, Long ve Ross, 1994; Long ve Ross, 1993; Mason ve Kendall, 1978).

Betimsel ve deneysel araştırmaların bu sonuçları, aynı zamanda metinlerin zorluk derecelerinin öğrencilerin okudukları metinlerde anlam oluşturmada etkili olduğunu ve metinler üzerinde yapılan değişimlerin ana dili ve yabancı dil öğrenicilerinin okuduğunu anlamaları üzerinde olumlu bir etkiye sahip olduğunu göstermektedir.

Illgili literatür incelendiğinde metinler üzerinde yapılan değişimler için sadeleştirme, düzenleme, kısaltma, revizyon gibi farklı kavramların kullanıldığı görülmektedir. Bu kavramların her birinin tanımlanması ve açıklanması için gerekli çalışmaların yapılarak bu konuda kavram birliğine varılması sağlanmalıdır.

$\mathrm{Bu}$ araştırma sonuçlarına göre metinlerin öğrencilerin okuduğunu anlama becerileri ile olan ilişkisi göz önünde bulundurulduğunda cümle uzunluğu, bilinmeyen sözcüklerin varlığı, eksiltili ifadeler, mantıksal sıralamanın önemli bir yere sahip olduğu görülmektedir. Bu nedenle ders kitaplarında yer alacak metinlerin seçilmesinde bu ölçütler ele alınarak değerlendirmeler yapılmalıdır.

Yapılan araştırmalara benzer şekilde bu araştırmada da metinlerin okunabilirlik düzeylerinin öğrencilerin okuduğunu anlama becerilerini olumlu yönde etkilediği sonucuna ulaşılmıştır. Bu nedenle, ders kitaplarına seçilecek metinlerin okunabilirlik düzeylerinin hesaplanmasıyla öğrencilerin sınıf seviyelerine göre belirlenerek bu konuda belli birtakım ölçütlerin geçerli olması sağlanmalıdır.

Ders kitaplarına seçilecek metinler üzerinde yapılan değişimlerin, metin dil bilimin sunduğu bilgiler doğrultusunda, alanında uzman kişiler tarafından yapılmasına özen gösterilmelidir.

Türk ve dünya edebiyatının klasikleşmiş tarihî metinlerinin küçük yaşta olan okurlar tarafından anlaşılması için metinlerde birtakım düzenlemeler yapıldığı görülmektedir. Ancak bu düzenlemelerin belli ölçütler doğrultusunda yapılmadığı görülmektedir. Bu araştırma sonuçlarından hareketle bu metinlerin anlamını koruyan yüzey yapı değişiklikleri yapılarak anlaşılabilirlikleri tespit edilebilir.

Türkiye'de seviyelendirilmiş okuma listelerinin bulunmaması nedeniyle, öğrencilerin seviyelerine uygun olan okuma kitaplarını tespit etmek zorlaşmaktadır. Bu nedenle, metinler üzerinde yapılacak değişimlerin okuma kitaplarına da uygulanarak öğrencilerin okuma düzeylerine uygun olarak seviye kitaplarının oluşturulması sağlanabilir.

Anlamı değiştirmeden yüzey yapıda yapılan değişimlerin öğrencilerin okuduğunu anlama becerilerine etkisi nicel ve nitel desende daha çok araştırmayla tespit edilmelidir. Bu şekilde, yapılacak araştırmaların sonuçları doğrultusunda metinler üzerinde yapılan değişimler için belirlenecek ölçütlerin daha güvenilir bir şekilde tespit edilmesi sağlanabilir.

Seviyelendirilmiş metinlerin öğrencilerin okuduğunu anlama becerileri üzerine olan etkisini ölçen deneysel araştırmalar yapılarak metinlerin öğrencilerin okuduğunu anlama becerilerini geliştirmede ihtiyaç duyulan düzenlemelerin tespit edilmesi sağlanabilir. 


\section{Kaynaklar}

Alyılmaz, C. (2010). Türkçe öğretiminin sorunları. Turkish Studies International Periodical For the Languages, Literature and History of Turkish or Turkic, 5(3), 728-749.

Ateşman, E. (1997). Türkçede okunabilirliğin ölçülmesi. A.Ü. Tömer Dil Dergisi, 58, 71-74.

Aydın, i. ve Torusdağ, G. (2014). Türkçe öğretimi çerçevesinde yazınsal bir çözümleme. Uluslararası Türkçe Edebiyat Kültür Eğitim Dergisi, 3 (4), 109-134.

Bakan, H. (2012). Yabancılara Türkçe öğretiminde metindilbilimsel ölçütler çerçevesinde bir sadeleştirme denemesi: Sait Faik Abasıyanık, "Meserret Oteli". Ankara: Ankara Üniversitesi Sosyal Bilimler Enstitüsü. Yayınlanmamış Yüksek Lisans Tezi.

Baş, B. ve Yıldız, F. (2015). 2. sınıf Türkçe ders kitabındaki metinlerin okunabilirlik açısından incelenmesi. Mersin Üniversitesi Eğitim Fakültesi Dergisi, 11 (1), 52-61.

Bayraktar, i. ve Durukan, E. (2016). Türkçe ders kitaplarında metin sadeleştirme üzerine bir değerlendirme. Uluslararası Türkçe Edebiyat Kültür Eğitim Dergisi, 5 (3), 1356-1369.

Büyüköztürk, Ş., Kılıç Çakmak, E., Akgün, Ö., Karadeniz, Ş. ve Demirel, F. (2012). Bilimsel araştırma yöntemleri. Ankara: Pegem Akademi.

Büyüköztürk, Ş. (2013). Sosyal bilimler için veri analizi el kitabı. Ankara: Pegem Akademi.

Creswell, J. W. (2016). Araştırma deseni nitel, nicel ve karma yöntem yaklaşımları (Çev. Ed. S. B. Demir). Ankara: Eğiten Kitap.

Çiftçi, Ö., Çeçen, M. ve Melanlıoğlu, D. (2007). Altıncı sınıf Türkçe ders kitaplarındaki metinlerin okunabilirlik açısından değerlendirilmesi. Elektronik Sosyal Bilimler Dergisi, 6 (22), 206-219.

Demirel, M. (1996). Bilgilendirici metin türünün ve okuduğunu kavrama becerisinin altıncı sınıf öğrencilerinin öğrenme düzeyine etkisi. Hacettepe Üniversitesi Eğitim Fakültesi Dergisi, 13, 245-254.

Durmuş, M. (2013a). İkinci/Yabancı dil öğretiminde özgün ve değiştirilmiş dilsel girdi üzerine. Turkish Studies International Periodical For the Languages, Literature and History of Turkish or Turkic, 8 (1), 1291-1306.

Durmuş, M. (2013b). İkinci/Yabancı dil öğretiminde sadeleştirilmiş metin sorunları üzerine. Bilig, 65, $135-150$.

Durukan, E. (2014). Metinlerin okunabilirlik düzeyleri ile öğrencilerin okuma becerileri arasındaki ilişki. Ana Dili Eğitimi Dergisi, 2 (3), 68-76.

Faigley, L. ve Witte, S. (1981). Analyzing revision. College Compositionand Communication, 400-414.

İskender, H. ve Yiğit, F. (2015). Küçük yapı düzeyindeki değişimlerin öğrencilerin metni anlamalarına ilişkin görüşleri üzerine etkisi. Mustafa Kemal Üniversitesi Sosyal Bilimler Enstitüsü Dergisi, 12 (32), 450-476.

Johnson, A. P. (2017). Okuma ve yazma öğretimi. Ankara: Pegem Akademi.

Karpuz, Ö. ve Akçataş, A. (2001). Metinde anlam bağları üzerine. A.Ü. Türkiyat Araştırmaları Enstitüsü Dergisi, 18, 37-47.

Kavcar, C. (1996). Anadili eğitimi. Ana Dili Dergisi, 1, 15-19.

Kökçü, Y. (2018). Metnin küçük yapı düzeyinde meydana gelen değişikliklerin öğrencilerin okuduğunu anlama becerisine etkisi. Turkish Studies International Periodical For the Languages, Literature and History of Turkish or Turkic, 12 (18), 421-436.

$\mathrm{Li}, \mathrm{Y}$., Xu S. ve Wang, Q. (2005). The effects of simplified and elaborated texts on second language reading comprehension: An exploratory study. Vigo International Journal of Applied Linguistics, 2, 45-74.

Long, M. H. ve Ross, S. (1993). Modifications that preserve language and content. In: Tickoo, M. L., Ed. Simplification: Theory and Application. Anthology Series, 31, 2952.

Mason, J. M. ve Kendall, J. (1978). Facilitating reading comprehension through text structure manipulation. Technical Report No. 92, 1-38.

Maxvell, S. (2011). The effects of two types of text modification on english language learners reading comprehension: sımplification versus elaboration. Minnesota: Hamline University.

Marshall, J. (1974). Ana dili öğretimi. İstanbul: Millî Eğitim Basımevi. 
Oh, S. (2001). Two types of input modification and EFL reading comprehension: Simplification versus elaboration. TESOL Quarterly, 35 (1), 69-96.

Okur, A. ve Arı, G. (2013). 6., 7., 8. sınıf Türkçe ders kitaplarındaki metinlerin okunabilirliği. Illköğretim Online, 12 (1), 202-226.

Onan, B. (2015). Derin yapı yüzey yapı ilişkisi bağlamında temel dil becerileri üzerine bir analiz çalışması. Ana Dili Eğitimi Dergisi, 3(3), 91-110.

Özdemir, E. (2018). Anadili öğretimi. Türk Dili Dil Öğretimi Özel Sayısı, 18-30.

Sallabaş, M. E. (2008). İlköğretim 8. sınıf öğrencilerinin okumaya yönelik tutumları ve okuduğunu anlama becerileri arasındaki ilişki. Inönü Üniversitesi Eğitim Fakültesi Dergisi, 9 (16), 141-155.

Tekin, H. (1984). Eğitimde ölçme ve değerlendirme. Ankara: Has-Soy Matbaası.

Yano, Y., Long, M. ve Ross, S. (1994). Effects of simplified and elaborated texts on foreign language reading comprehension. Language Learning, 44 (2), 189-219.

Yıldırım, A. ve Şimşek, H. (2011). Sosyal bilimlerde nitel araştırma yöntemleri. Ankara: Seçkin Yayıncilık.

Zorbaz, K. Z. (2007). Türkçe ders kitaplarındaki masalların kelime-cümle uzunlukları ve okunabilirlik düzeyleri üzerine bir değerlendirme. Eğitimde Kuram ve Uygulama, 3 (1), 87-101.

\section{Extended Abstract}

\section{Introduction}

Texts that constitute the focal point of Turkish courses, forming meaning from texts, text types and quality of texts became more important with the use of textbooks as an important material. As a result of text-based teaching, teachers also had to evaluate their students' reading, understanding and interpretation skills. In this case, the ability to read, construct meaning, inferences and interpretations correctly and effectively has become the subject of today's language and mind studies(Bayraktar ve Durukan, 2016). For this reason, it is seen that the relationship between reading skills and the reception of texts has been examined in recent years.

It is seen that many studies have been done on the texts in the textbooks as they are the most commonly used course materials both in Turkish and other courses. However, the lack of an applied study on the relationship between the changes in the texts and the reading comprehension skills of the students is an important deficiency.

Therefore, the lack of studies that reveal the relationship between the changes in the texts in the relevant literature and the students' reading comprehension skills forms the reason of the research. Based on the idea that the texts selected in the textbooks should be arranged in a way that will help the students to construct meaning, it is thought that this study will contribute to the related literature.

\section{Method}

In the research, mixed method design was used. Mixed method design is a method that requires combining or integrating qualitative and quantitative researches and the data obtained from these studies. It is seen that convergent design, exploratory sequential design and exploratory sequential design models are used in social sciences in the field of mixed methods (Creswell, 2016).

In this research, data were collected by quantitative and qualitative data collection techniques. In the research, quantitative data were used to determine the general achievement levels of reading comprehension, readability levels of texts, achievement levels of reading comprehension of students and attitudes towards reading; qualitative data were used to determine the views of students for the changes made on the texts.

The reason for collecting quantitative and qualitative data together is to determine whether the findings obtained from both databases confirm each other and to ensure that the research problem is fully understood. Quantitative data of the research was collected through a reading comprehension achievement test, the Ateşman Readability Formula, Akşamla Gelen Reading Comprehension Questions, Tac Mahal Reading Comprehension Questions and a Reading Attitude Scale; the qualitative data was collected through a Student Questionnaire Focusing on the Changes 
Made on the Texts. The quantitative and qualitative data of the research were collected together during the research process.

\section{Result and Discussion}

According to the results of the research: there was a significant difference in the reading success scores of the students with low and medium reading success in the narrative text type; there was no significant difference in reading achievement scores of students with high reading success. As to the informative text type, It was found that there was a significant difference in reading achievement scores of all student levels. This result reveals that surface structure changes are more functional in the informative text type.

When the responses of the students participating in the research to the Student Questionnaire Focusing on the Changes Made on the Texts were evaluated, it was concluded that the majority of the students expressed positive opinions about the changes made on the texts. The students stated that the words and sentences in the texts whose surface structure was changed were better understood; the words and sentences in original texts whose surface structure was not changed were more difficult to understand.

According to the results of the research, it is seen that there is a meaningful relationship between the difficulty levels of informative and narrative texts and students' reading comprehension skills. These results show that surface structure changes made on the texts that students have difficulty in understanding contribute to the construction of meaning more easily. 